\title{
Resilient sealing materials for solid oxide fuel cells
}

\author{
Final Technical Report \\ Reporting period: 10/1/04-9/30/06 \\ Principal authors: Signo T. Reis and Richard K. Brow \\ February 2007 \\ DOE Award Number: DE-FG26-04NT42175 \\ University of Missouri-Rolla \\ Department of Materials Science \& Engineering \\ Rolla, MO 65409
}




\section{DISCLAIMER}

"This report was prepared as an account of work sponsored by an agency of the United States Government. Neither the United States Government nor any agency thereof, nor any of their employees, makes any warranty, express or implied, or assumes any legal liability or responsibility for the accuracy, completeness, or usefulness of any information, apparatus, product, or process disclosed, or represents that its use would not infringe privately owned rights. Reference herein to any specific commercial product, process, or service by trade name, trademark, manufacturer, or otherwise does not necessarily constitute or imply its endorsement, recommendation, or favouring by the United States Government or any agency thereof. The views and opinions of authors expressed herein do not necessarily state or reflect those of the United States Government or any agency thereof." 


\begin{abstract}
This report describes the development of 'invert' glass compositions designed for hermetic seals in solid oxide fuel cells (SOFC). Upon sealing at temperatures compatible with other SOFC materials (generally $\leq 900^{\circ} \mathrm{C}$ ), these glasses transform to glass-ceramics with desirable thermo-mechanical properties, including coefficients of thermal expansion (CTE) over $11 \times 10^{-6} /{ }^{\circ} \mathrm{C}$. The long-term (>four months) stability of CTE under SOFC operational conditions (e.g., $800^{\circ} \mathrm{C}$ in wet forming gas or in air) has been evaluated, as have weight losses under similar conditions. The dependence of sealant properties on glass composition are described in this report, as are experiments to develop glass-matrix composites by adding second phases, including Ni and YSZ. This information provides design-guidance to produce desirable sealing materials.
\end{abstract}




\section{Table of Contents}

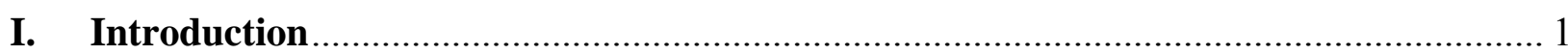

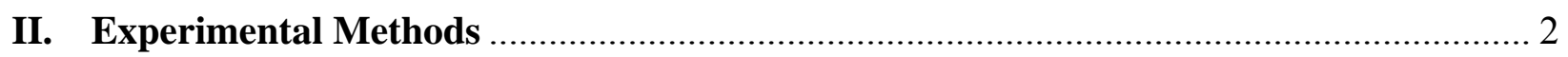

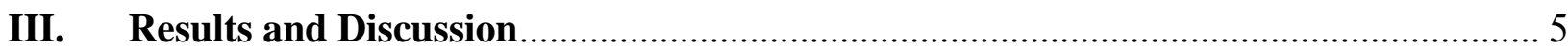

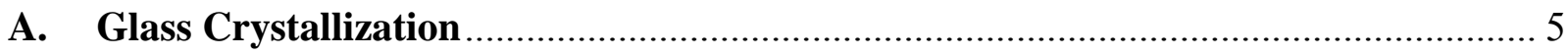

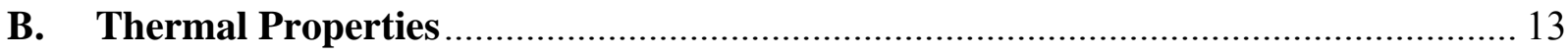

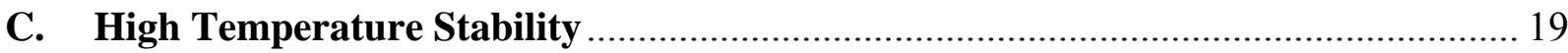

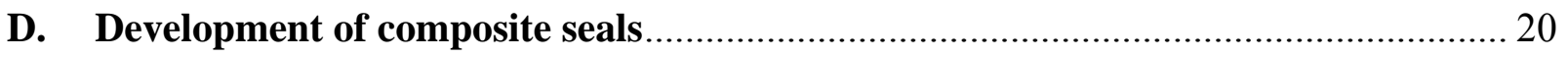

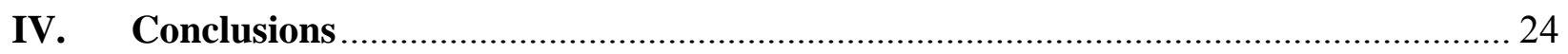




\section{EXECUTIVE SUMMARY}

This report describes the development of alkaline-earth-based silicate glasses for seals for solid oxide fuel cells (SOFCs). The glasses have relatively low silica contents $(<45$ mole\%) and so possess molecular-level structures much less connected than conventional silicate glasses. These depolymerized structures contribute to desirably low viscosities at sealing temperatures $\left(<900^{\circ} \mathrm{C}\right)$, and lead to the formation of crystalline phases that possess relatively high coefficients of thermal expansion (CTE in the range 10$12 \times 10^{-6} /{ }^{\circ} \mathrm{C}$ ) and good thermal stability when the glasses are crystallized to form stable glass-ceramics.

We have prepared and characterized over forty glass compositions and we review the composition-property relationships and the performance requirements desired for SOFC seals. In particular, we will review how the choice of alkaline earth oxide and their relative concentrations affect desirable thermal properties. For example, the CTE can be tailored by varying the relative $\mathrm{ZnO}, \mathrm{CaO}$, and $\mathrm{SrO}$ contents: greater $[\mathrm{SrO}+\mathrm{CaO}]$ contents increase CTE, but reduce the 'glass-forming tendency', as determined by differential thermal analyses. Increasing the $\mathrm{ZnO}$-content improves the glass-forming tendency, but reduces the CTE of the crystallized material. The addition of boron oxide $\left(\mathrm{B}_{2} \mathrm{O}_{3}\right)$ also improves glass-forming tendency and appears to help stabilize a residual glassy-phase in the crystallized glass-ceramic.

We will also review how glass components affect seal stability under SOFC operational conditions. For example, with a particular focus on the thermo-mechanical properties of the glass-ceramics over extended times at SOFC operational temperatures; e.g., $700-800^{\circ} \mathrm{C}$. In addition, the thermo-chemical stability of the glass-ceramics, as measured by weight losses under wet, reducing conditions at elevated temperatures, were characterized as a function of glass composition. For example, additions of $\mathrm{B}_{2} \mathrm{O}_{3}$ produce glass-ceramics with a greater fraction of residual glassy phase that reduces the crystallization rates, but increases the volatility (weight loss) of glasses at $800^{\circ} \mathrm{C}$ in wet forming gas.

Glass crystallization kinetics have been evaluated using a modified Avrami analysis, and this work will be published in an upcoming issue of the Journal of the American Ceramic Society. This thermal analytical technique allows us to consider how changes in the glass composition, changes in the glass particle size, and the presence of a second phase, all affect crystallization kinetics. By doing so, useful processing information is provided that guides the development of sealing glass tapes and pastes that are compatible with SOFC manufacturing processes. In general, crystallization rates increase with smaller particle sizes and with the presence of second phases used to create glassmatrix composites. The former behaviour sets lower limits on glass particle size that can be used to provide dense glass seals before crystallization impedes glass flow during the sealing step.

Processes were also developed to prepare glass-matrix composites with the 'invert' glasses and with a variety of 'filler' materials, including nickel metal powders and Ystabilized zirconia (YSZ) powders to tailor the thermal expansion characteristics of the composite. For example, the addition of $10 \mathrm{vol} \% \mathrm{Ni}$ particles to glass \#27 will increase CTE by $10 \%$, from $\sim 10 \times 10^{-6} /{ }^{\circ} \mathrm{C}$ to $\sim 11 \times 10^{-6} /{ }^{\circ} \mathrm{C}$, while accelerating the crystallization 
kinetics of the glass matrix. The Ni particles show no evidence for reactions with the glassy matrix after extended times at SOFC operational temperatures.

The glasses and the glass-matrix composites have been used to fabricate hermetic seals for SOFC components and the performance of these seals will be described in the final report for SECA project DE-FG26-04NT42221. 


\section{Introduction}

Solid oxide fuel cells (SOFCs) convert chemical energy to electricity via an electrochemical reaction and are projected to become important alternative energy sources because of their high efficiency and low emissions [1-2]. Planar SOFC designs require simple manufacturing processes, have relatively short current paths and produce higher power densities and efficiencies than tubular designs [2]. In order for a planar SOFC to properly operate, a suitable sealant is required to prevent the fuel gas and air from mixing. The sealant must possess thermo-mechanical characteristics that are compatible with other SOFC components (i.e., the electrolyte and interconnects), must resist deleterious, high temperature interfacial reactions with those components, must be an electrical insulator, and must remain thermo-chemically stable in fuel cell operating environments, which include a range of environments ( $\mathrm{p}_{\mathrm{O} 2}$ and $\left.\mathrm{p}_{\mathrm{H} 2 \mathrm{O}}\right)$, temperatures on the order of $800^{\circ} \mathrm{C}$, for times up to 50,000 hours $[1,2,3,4]$. In many ways, the seal performance will control the structural integrity and mechanical stability of the SOFC stack, and could also determine the overall stack performance [3].

There have been many reports on the development of a variety of compositional systems to form suitable glass and glass-ceramics seals for SOFCs, including silicates, aluminosilicates, borosilicates, and aluminophosphates; i.e., see reference [5] and references therein. Many of these sealing materials have property or performance shortcomings. Some fail to remain thermo-mechanically stable under SOFC operational conditions, and others undergo deleterious interfacial reactions with other SOFC components. One such reaction occurs between $\mathrm{BaO}$-containing sealants and the $\mathrm{Cr}$ oxide scale that forms on interconnect alloys, resulting in the formation of a $\mathrm{BaCrO}_{4}$ interfacial phase that can adversely affect the mechanical integrity of the seal $[3,6]$.

The work at UMR has concentrated on glass compositions with relatively high concentrations of alkaline earth oxide (and $\mathrm{ZnO})$ and low concentrations of silica $(<40$ mole $\% \mathrm{SiO}_{2}$ ) that produce glass structures based on small silicate anions that are linked by a continuous network of modifier polyhedra. These 'depolymerized structures' have been classified as 'invert glasses' [7]. The 'basic oxide' network produces a glass with a relatively high glass transition temperature $\left(\mathrm{T}_{\mathrm{g}}\right)$, generally over $600^{\circ} \mathrm{C}$, and determines the coefficient of thermal expansion (CTE). The lack of a continuous silicate network 
leads to significant decreases in melt viscosities at temperatures above $T_{g}$, making it possible for the glasses to initially flow into the porous electrodes to a depth sufficient to achieve edge sealing of the PEN (Positive electrode/Electrolyte/Negative electrode) structure at the relatively low temperatures desired to avoid degradation of certain SOFC components. Further flow, however, would be limited when the glass is crystallized to form a glass-ceramic. Seals can be made at temperatures at or below $900^{\circ} \mathrm{C}$ and the crystallized glasses have thermal expansion coefficients in the range $10-12 \times 10^{-6} /{ }^{\circ} \mathrm{C}$. The crystallized phases are typically mixtures of pyro- and orthosilicate phases that reflect the low silica content of the original glass.

In this report, we review the compositional design of invert sealing glasses and the relationships between glass compositions and properties. We also review our differential thermal analysis (DTA) studies of glass crystallization behaviour, and the development of

glass-filler composites. The performance of hermetic seals prepared with 'invert' sealing glasses will be reviewed in a subsequent report for SECA project DE-FG26-04NT42221.

\section{Experimental Methods}

Glasses were prepared from mixtures of reagent grade alkaline earth carbonates and silica, with concentrations of other oxides, including $\mathrm{ZnO}, \mathrm{Al}_{2} \mathrm{O}_{3}$, and $\mathrm{TiO}_{2}$, to modify melt and glass properties. Most compositions contained $\mathrm{B}_{2} \mathrm{O}_{3}$, which was usually added to the glass batch as $\mathrm{H}_{3} \mathrm{BO}_{3}$. The batches were melted in platinum crucibles in air for fours hours, typically at $1550^{\circ} \mathrm{C}$. A typical melt size was approximately 50 grams, although melts as large as one kilogram have been made. Melts were quenched on steel plates and glasses were annealed for six hours near the appropriate glass transition temperature. The compositional ranges for the glasses under investigation are (in $\mathrm{mol} \%$ ) (0-30) $\mathrm{CaO},(0-30) \mathrm{SrO},(0-30) \mathrm{ZnO},(1-7) \mathrm{B}_{2} \mathrm{O}_{3},(2-4) \mathrm{Al}_{2} \mathrm{O}_{3},(0-2) \mathrm{TiO}_{2}$, and (35-45) $\mathrm{SiO}_{2}$, with a particular emphasis on compositions that would yield 'invert' glass structures. Other oxides, including $\mathrm{BaO}$, have been used in some compositions to evaluate their effects on glass properties and performance. The 'as batched' glass compositions (mole\%) prepared for this study are listed in Table 1. 
Glass powders (sieved to 45-75 $\mu \mathrm{m}$ ) were used for differential thermal analysis (DTA) experiments, using a Perkin-Elmer DTA-7. The powders were heated in air at $10^{\circ} \mathrm{C} / \mathrm{min}$ to determine the glass transition temperature, $\mathrm{T}_{\mathrm{g}}$, and crystallization temperature, $T_{c}$. Glass powders were crystallized by heat treating at temperatures around $T_{c}$ for one hour in an argon atmosphere and the crystalline phases were identified by $\mathrm{x}$ ray diffraction (XRD), using a Scintag XDS200X diffractometer. The thermal expansion characteristics of glass and crystallized samples were determined by dilatometric analyses, using an Orton model 1600D. Crystallized samples were prepared by first sintering, then crystallizing glass powders in graphite moulds $(25 \times 10 \mathrm{~mm})$ under argon for the indicated time and temperature. Dilatometric data was collected by heating samples in air at $3^{\circ} \mathrm{C} / \mathrm{min}$, to determine the coefficient for thermal expansion (CTE) and dilatometric softening points $\left(T_{d}\right)$.

Chemical stability of crystallized glass samples in reducing environments was evaluated by measuring the weight loss from bulk samples (10 $\mathrm{mm} \times 10 \mathrm{~mm} \times 10 \mathrm{~mm})$ held in wet, flowing forming gas $\left(10 \% \mathrm{H}_{2}, 90 \% \mathrm{~N}_{2}\right)$ at $800^{\circ} \mathrm{C}$ for up to 42 days. The samples were polished to a 600 grit finish with $\mathrm{SiC}$ paper, cleaned with acetone and supported by a $\mathrm{Ni} / \mathrm{Cr}$ wire in the furnace. The measurements were made for each crystallized glass sample and the average weight loss, normalized to the glass surface area, was determined.

Composite powders were prepared by ball-milling with water glass powders $(<53$ $\mu \mathrm{m})$ that were mixed with up to $10 \mathrm{vol} \% \mathrm{Ni}(\sim 3 \mu \mathrm{m}$ diameter $)$ or YSZ ( $\sim \mu \mathrm{m}$ diameter) for 24 hours to produce uniform mixtures. The resulting slurry was dried in an oven at $90^{\circ} \mathrm{C}$ for several days to produce samples for DTA experiments analyses and for preparing test sealing materials. 
Table 1: Molar compositions of sealing glasses prepared for this study.

\begin{tabular}{|c|c|c|c|c|c|c|c|c|c|}
\hline Glass ID & $\mathrm{CaO}$ & SrO & $\mathrm{BaO}$ & ZnO & $\mathrm{NiO}$ & $\overline{\mathbf{B}_{2} \mathbf{O}_{3}}$ & $\mathbf{A l}_{2} \mathbf{O}_{3}$ & $\mathrm{SiO}_{2}$ & $\mathrm{TiO}_{2}$ \\
\hline G25 & 3.23 & 50 & 0.00 & 323 & 0.00 & 4.90 & 2.94 & 39.20 & 2.00 \\
\hline GB27 & 9.62 & 18.88 & 0.00 & 13.50 & 0.00 & 1.94 & 3.00 & 43.00 & 0.00 \\
\hline G27 & 19.23 & 18.50 & 0.00 & 13.23 & 0.00 & 1.90 & 2.94 & 42.20 & 2.00 \\
\hline G29 & 20.00 & 20.00 & 0.00 & 10.00 & 0.00 & 2.00 & 3.00 & 43.00 & 2.00 \\
\hline G32 & 19.23 & 18.50 & 13.23 & 0.00 & 0.00 & 1.90 & 2.94 & 42.20 & 2.00 \\
\hline G34 & 26.00 & 26.00 & 0.00 & 0.00 & 0.00 & 4.00 & 2.00 & 42.00 & 0.00 \\
\hline G35 & 25.48 & 25.48 & 0.00 & 0.00 & 0.00 & 3.92 & 1.96 & 41.16 & 2.00 \\
\hline G36 & 26.48 & 26.48 & 0.00 & 0.00 & 0.00 & 2.00 & 1.96 & 41.08 & 2.00 \\
\hline G38 & 0.00 & 26.00 & 0.00 & 26.00 & 0.00 & 4.00 & 2.00 & 42.00 & 0.00 \\
\hline G39 & 24.00 & 26.00 & 0.00 & 2.00 & 0.00 & 7.00 & 2.00 & 39.00 & 0.00 \\
\hline G40 & 13.00 & 26.00 & 0.00 & 13.00 & 0.00 & 4.00 & 2.00 & 42.00 & 0.00 \\
\hline G41 & 0.00 & 26.00 & 0.00 & 26.00 & 0.00 & 2.00 & 2.00 & 44.00 & 0.00 \\
\hline G42 & 13.00 & 26.00 & 0.00 & 13.00 & 0.00 & 2.00 & 2.00 & 42.00 & 2.00 \\
\hline G43 & 19.23 & 18.50 & 0.00 & 13.23 & 0.00 & 1.90 & 2.90 & 42.20 & 2.00 \\
\hline G44 & 17.20 & 21.50 & 0.00 & 12.26 & 0.00 & 1.90 & 2.94 & 42.20 & 2.00 \\
\hline G45 & 15.20 & 24.50 & 0.00 & 11.26 & 0.00 & 1.90 & 2.94 & 42.20 & 2.00 \\
\hline G46 & 20.00 & 20.00 & 0.00 & 10.00 & 0.00 & 2.00 & 3.00 & 43.00 & 2.00 \\
\hline G48 & 15.20 & 28.48 & 0.00 & 7.26 & 0.00 & 1.90 & 2.94 & 42.20 & 2.00 \\
\hline G49 & 26.00 & 26.00 & 0.00 & 4.00 & 0.00 & 2.00 & 2.00 & 40.00 & 0.00 \\
\hline G50 & 25.48 & 25.48 & 0.00 & 3.92 & 0.00 & 1.96 & 1.96 & 39.20 & 2.00 \\
\hline G51 & 16.00 & 28.00 & 0.00 & 0.00 & 0.00 & 4.00 & 4.00 & 44.00 & 4.00 \\
\hline G52 & 12.00 & 31.00 & 0.00 & 4.00 & 0.00 & 4.00 & 4.00 & 41.00 & 4.00 \\
\hline G53 & 12.00 & 31.00 & 0.00 & 0.00 & 4.00 & 4.00 & 4.00 & 41.00 & 4.00 \\
\hline G54 & 25.42 & 25.42 & 0.00 & 0.00 & 4.00 & 1.92 & 1.88 & 39.44 & 1.92 \\
\hline G57 & 16.00 & 28.00 & 0.00 & 0.00 & 0.00 & 32.00 & 4.00 & 20.00 & 0.00 \\
\hline G58 & 0.00 & 20.00 & 20.00 & 0.00 & 0.00 & 10.00 & 0.00 & 50.00 & 0.00 \\
\hline G59 & 0.00 & 20.00 & 20.00 & 0.00 & 0.00 & 20.00 & 0.00 & 40.00 & 0.00 \\
\hline G60 & 0.00 & 20.00 & 20.00 & 0.00 & 0.00 & 30.00 & 0.00 & 30.00 & 0.00 \\
\hline G61 & 0.00 & 20.00 & 20.00 & 0.00 & 0.00 & 40.00 & 0.00 & 20.00 & 0.00 \\
\hline G62 & 19.23 & 18.50 & 13.23 & 0.00 & 0.00 & 5.90 & 2.94 & 40.20 & 0.00 \\
\hline G63 & 19.23 & 18.50 & 13.23 & 0.00 & 0.00 & 8.80 & 0.00 & 40.20 & 0.00 \\
\hline G64 & 25.50 & 25.50 & 0.00 & 3.90 & 0.00 & 6.10 & 0.00 & 39.00 & 0.00 \\
\hline G65 & 25.50 & 25.50 & 0.00 & 5.90 & 0.00 & 1.90 & 2.00 & 39.20 & 0.00 \\
\hline
\end{tabular}




\section{Results and Discussion}

Two glass compositions, designated glass \#27 and glass \#50, were identified as having desirable thermo-mechanical and thermo-chemical properties for SOFC seals. These two compositions, therefore, are principally used below to provide examples for the behaviour of 'invert' glasses.

\section{A. Glass Crystallization}

Figure 1 shows examples of differential thermal analysis (DTA) curves collected from glass \#50 'as cast', after initial crystallization during a typical sealing treatment $\left(850^{\circ} \mathrm{C}\right.$ for two hours), and after 30 days at $800^{\circ} \mathrm{C}$. The DTA curve from the 'as cast' sample exhibits an endothermic glass transition $\left(\mathrm{T}_{\mathrm{g}}\right)$ near $740^{\circ} \mathrm{C}$ and two exothermic crystallization peaks $\left(\mathrm{T}_{\mathrm{c}}\right)$ near $931^{\circ} \mathrm{C}$ and $1015^{\circ} \mathrm{C}$. The $\mathrm{T}_{\mathrm{g}}$ endotherm is not detected in the 'as sealed' glass \#50 and the relative intensities of the two crystallization exotherms are reduced, indicating a reduction in the fraction of residual glass in this sample. (The relationship between the DTA exotherms and the fraction of residual glass in a partiallycrystallized glass-ceramic is discussed in more detail below.) There is no evidence for a glass transition or for the crystallization peaks in the DTA curve collected from the sample heat-treated for thirty days, indicating that the original sealing glass has crystallized to a thermodynamically more stable form over the course of time. Figure 1 is representative of the DTA data collected from all samples evaluated in this study and this data was used to select sealing temperatures and crystallization temperatures for subsequent studies of the crystallized versions of these glasses.

Figure 2 shows x-ray diffraction (XRD) data collected from 'as cast' and 'as sealed' samples of glass \#50. The XRD pattern from the 'as cast' glass is a broad, featureless pattern that is typical of an oxide glass. The 'as sealed' diffraction sample, however, includes several sets of peaks that identify the major crystalline phases that make up the sealing materials. In this case, those phases are $(\mathrm{Ca}, \mathrm{Sr}) \mathrm{SiO}_{3}, \mathrm{CaSrSiO}_{4}$ and $\mathrm{Sr}_{2} \mathrm{Al}_{2} \mathrm{SiO}_{7}$. (These assignments were confirmed in an analysis done by Prof. Scott Misture (Alfred 
University) and that data will be discussed in the final report for project DE-FG2604NT42221.) The diffraction data shown in

Figure 2 are representative of data collected from all invert glasses prepared in this study.

The ability of a melt to form a glass upon cooling is known as the glass forming tendency and is often characterized by empirical rules. Differential thermal analyses, like those shown in Figure 1, provide useful information about the glass forming tendency. For example, melts that possess large differences between their crystallization and glass transition temperatures, $\Delta T=\left(T_{c}-T_{g}\right)$, tend to more readily form glasses upon cooling [8]. As shown in Figure 3, additions of $\mathrm{ZnO}$ increase the glass-forming tendencies of the "invert" silicate glasses examined in this study.

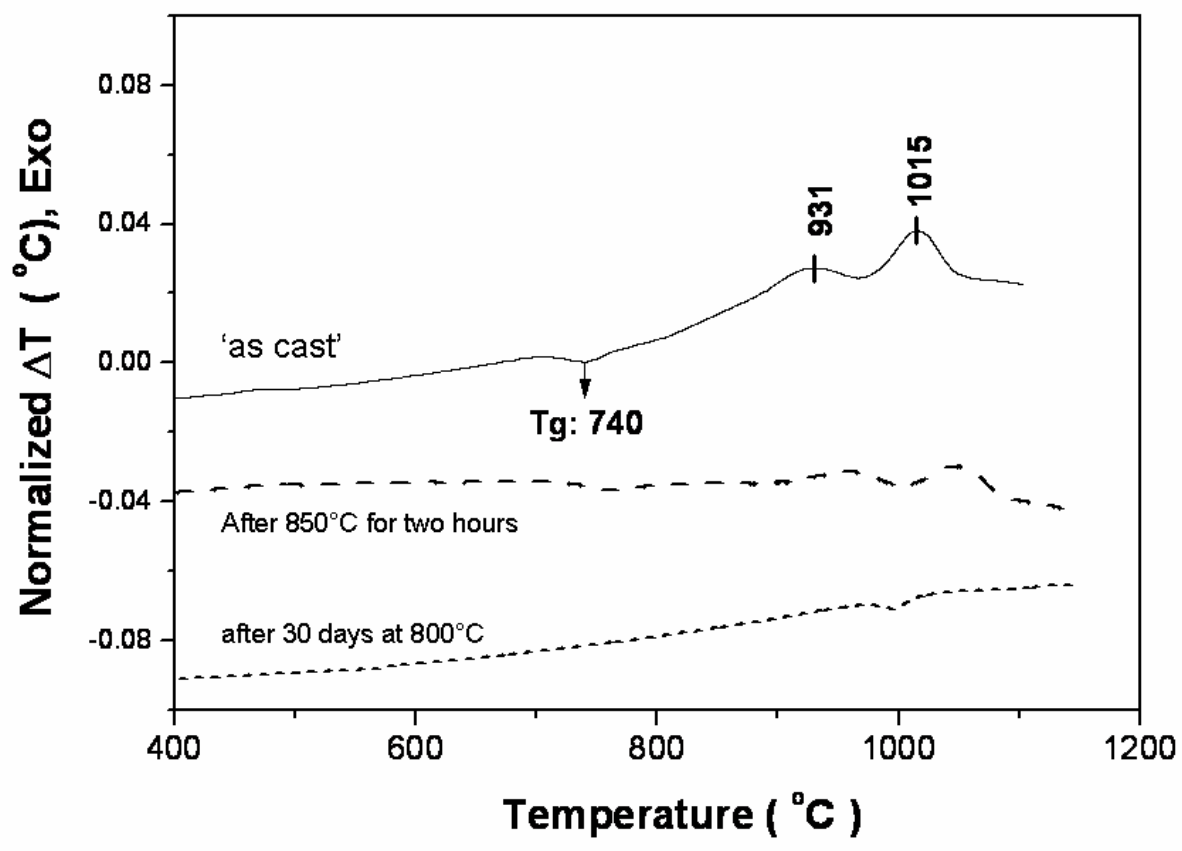

Figure 1: Differential thermal analysis data collected from glass \#50 in the 'as cast' state (top), after a typical sealing treatment $\left(850^{\circ} \mathrm{C}\right.$ for two hours) (middle), and after 30 days at $800^{\circ} \mathrm{C}$ (bottom). 

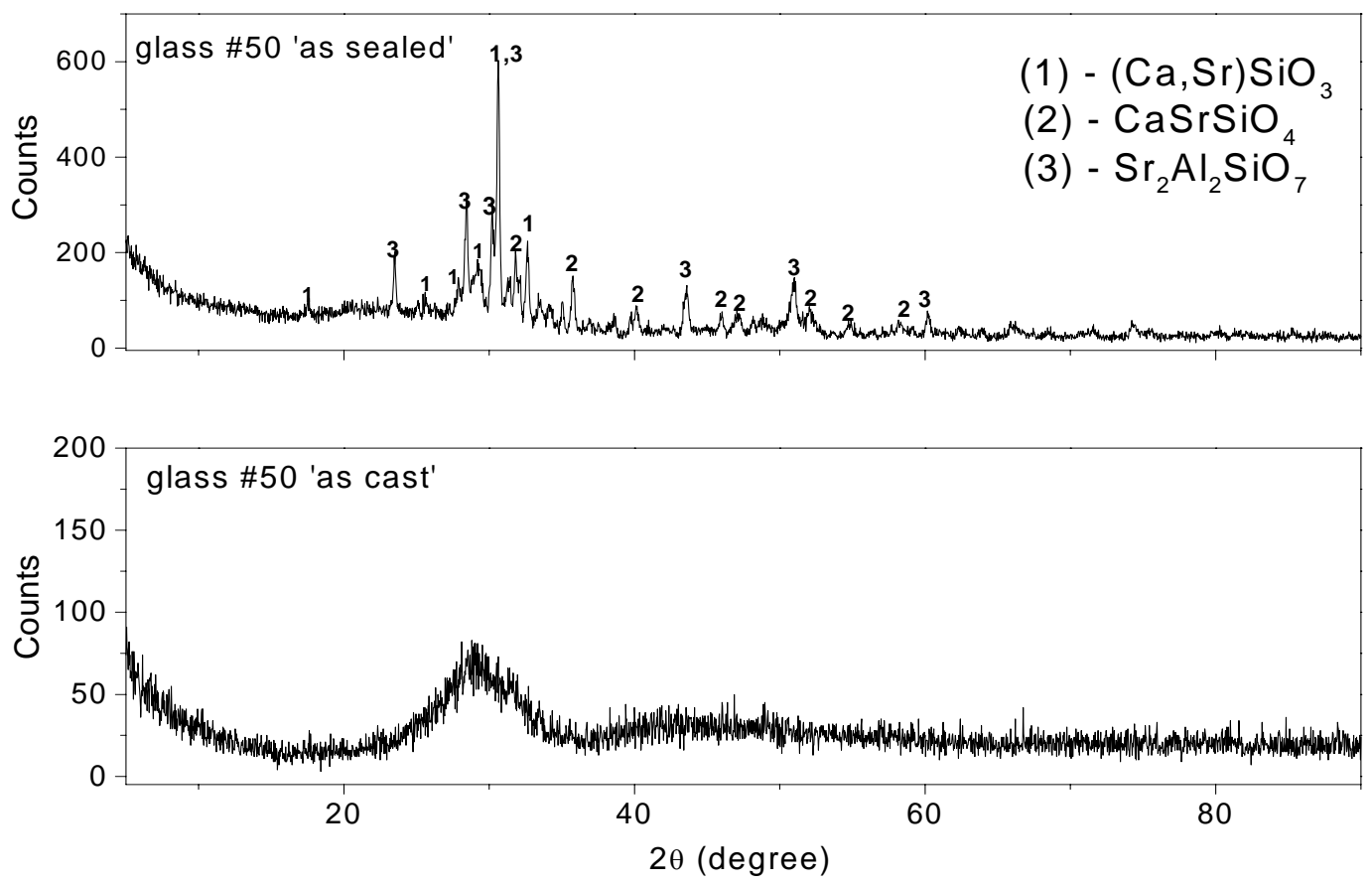

Figure 2: X-ray diffraction data for glass \#50 'as cast' (bottom) and after a typical sealing treatment $\left(850^{\circ} \mathrm{C}\right.$ for two hours) (top).

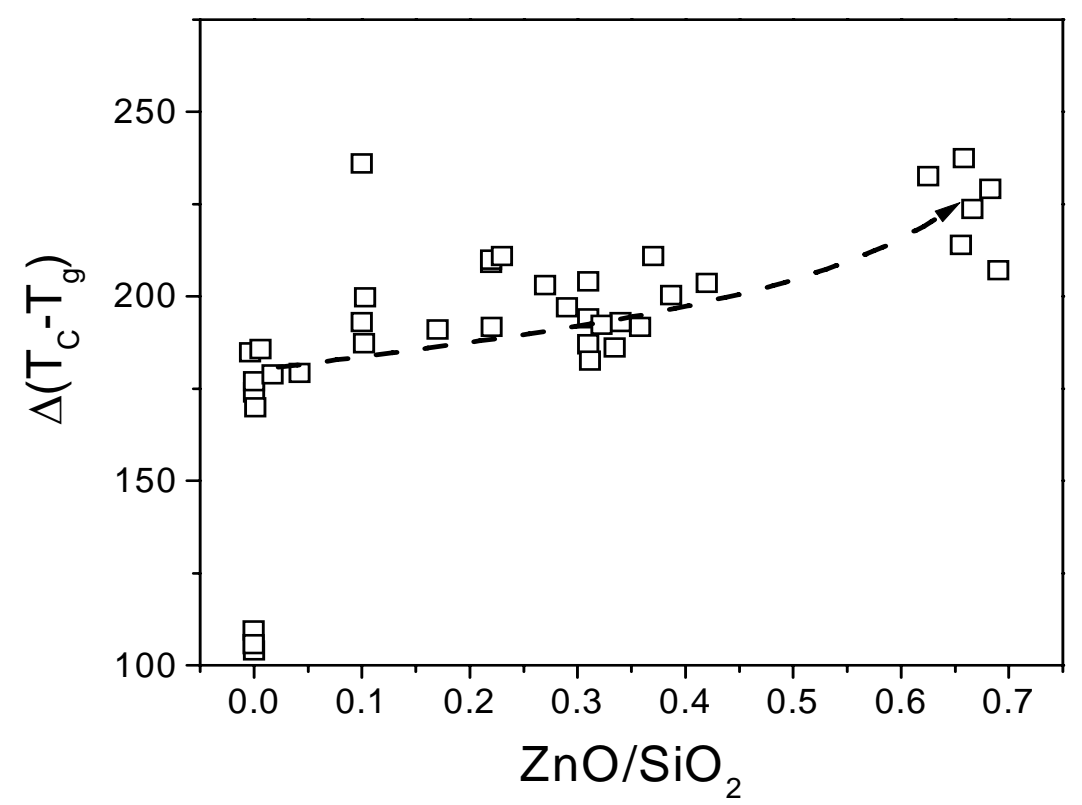

Figure 3: Glass forming tendency versus molar ratio $\mathrm{ZnO} / \mathrm{SiO}_{2}$ ratio. The dashed line is a guide for the eyes. 
A more detailed study of the crystallization behaviour of glass \#27 is described in reference [9] and is summarized here. This study includes the development of a DTA technique to characterize crystallization kinetics. The crystallization kinetics of a glass can be described by the relationship [10]:

$$
\mathrm{x}=1-\exp \left[-(\mathrm{kt})^{\mathrm{n}}\right]
$$

where $\mathrm{x}$ is the volume fraction crystallized after time $\mathrm{t}, \mathrm{n}$ is the Avrami exponent, and $\mathrm{k}$ is the reaction-rate constant, whose temperature dependence is expressed by the Arrhenius equation:

$$
\mathrm{k}=\mathrm{k}_{0} \exp [-\mathrm{E} / \mathrm{RT}]
$$

where $\mathrm{k}_{0}$ is the frequency factor, $\mathrm{E}$ is the activation energy, $\mathrm{R}$ is the gas constant, and $\mathrm{T}$ is the isothermal temperature in Kelvins. Generally, the logarithmic form of Eq. (1) is preferred:

$$
\ln [-\ln (1-\mathrm{x})]=\mathrm{n} \ln \mathrm{t}+\mathrm{n} \ln \mathrm{k}
$$

During crystallization, an exothermic peak is observed because the enthalpy of the crystal is lower than that of glass; e.g., Figure 1 (top). The area under the DTA crystallization peak is assumed to be proportional to the heat of crystallization in this experiment. Since a fraction of a glass sample will be crystallized during the initial isothermal hold in the DTA, the area under the crystallization peak that forms upon reheating the sample must then represent the volume fraction of the residual glass after the preceding isothermal heat treatment. Therefore, the volume faction crystallized (x) after time $t$ can be expressed as $\left(\mathrm{A}_{0}-\mathrm{A}\right)$, where $\mathrm{A}_{0}$ is the DTA peak area of a quenched glass powder (no crystallization), and A is the DTA peak area of glass powder after an isothermal heat treatment. Crystallization during heat-up and cool-down can be neglected since the fraction crystallized during these steps is much less than that generated from the isothermal hold.

Substituting (A / $\left.A_{0}\right)$ for (1-x) in equation (3) yields

$$
\ln \left[\ln \left(\mathrm{A}_{0} / \mathrm{A}\right)\right]=\mathrm{n} \ln \mathrm{t}+\mathrm{n} \ln \mathrm{k}
$$


and this equation is used to analyze the DTA data [9]. At a given temperature, values of $\mathrm{n}$ and $\mathrm{k}$ are determined using Eq.(4). The activation energy $\mathrm{E}$ and frequency factor $\mathrm{k}_{0}$, are then determined using the logarithmic form of Eq. (2).

Figure 4 shows the volume fraction of glass \#27 that is crystallized as a function of the isothermal heat treatment time at different temperatures for glass powders with initial particle size of $\sim 10 \mu \mathrm{m}$; increasing the isothermal temperature increases the crystallization kinetics.

At each temperature, values of the Avrami exponents, $\mathrm{n}$, and rate constants, $\mathrm{k}$, were determined by least-squares fitting of Eq.(4). A set of these analyses are shown in Figure 5 and summarized in Table 2. Activation energy (E) and the frequency factor $\left(\mathrm{k}_{0}\right)$ were obtained by least-squares fitting of Eq. (2), as shown in Figure 6. Table 3 summarizes the activation energies and Avrami parameters (n) determined for all samples with different particle sizes.

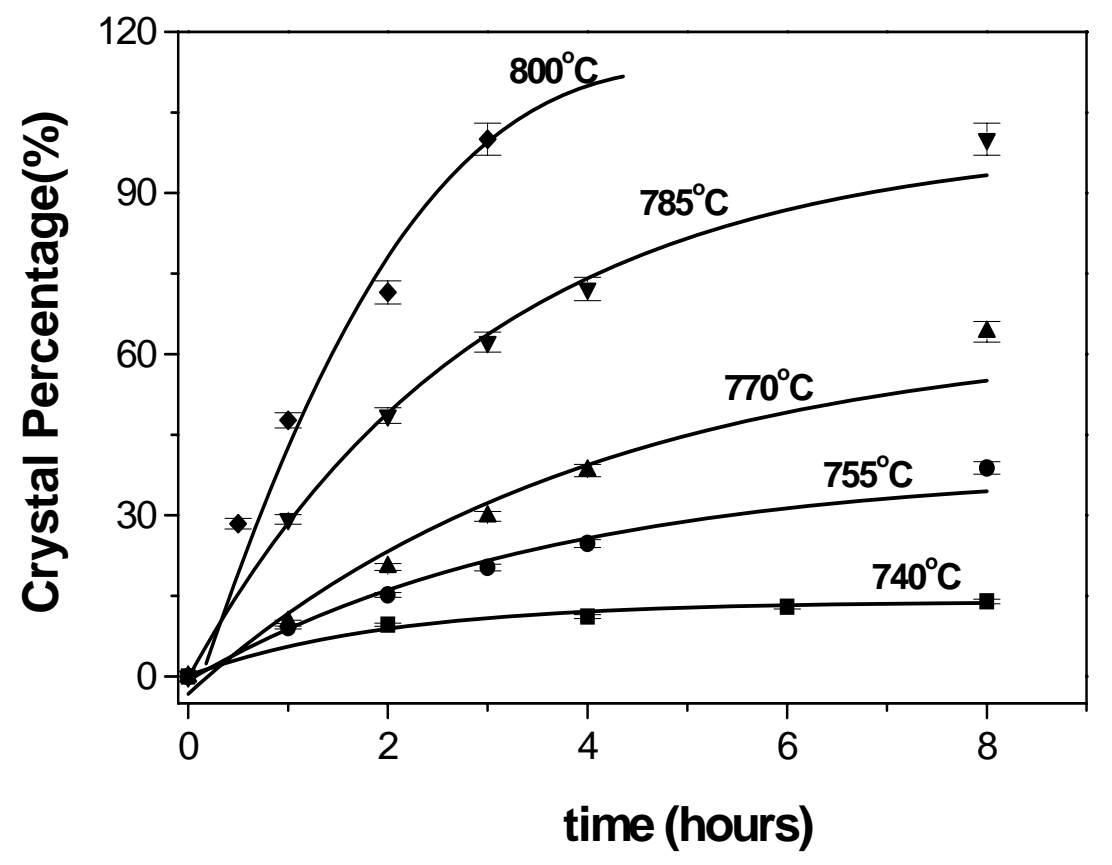

Figure 4: Crystal volume fraction in glass \#27 powders (with particle size of $\sim 10 \mu \mathrm{m}$ ) as a function of time after isothermal heat treatments. The solid lines are fit curves using respective $n$ values for each temperature (Table 2). 


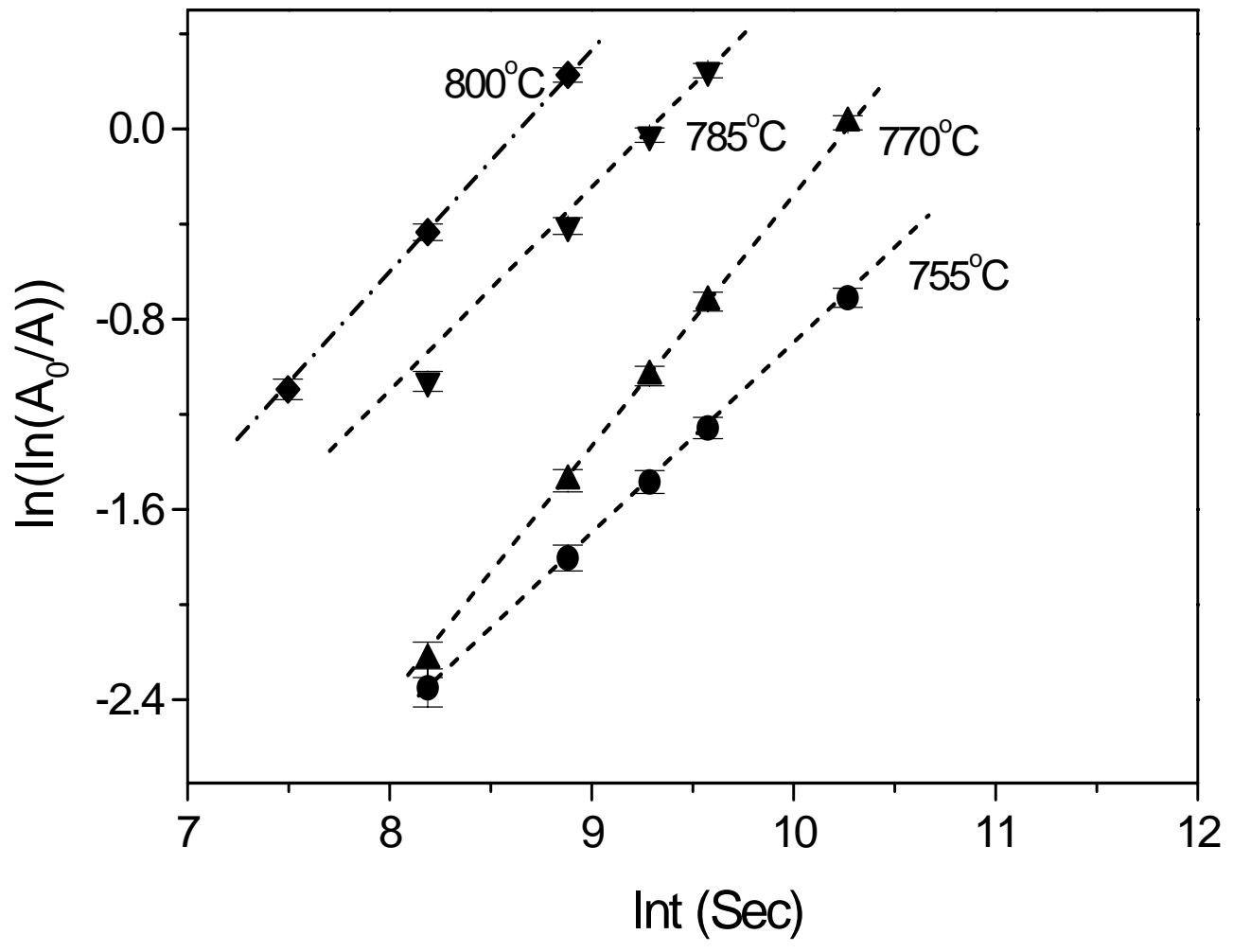

Figure 5: JMA fit for glass \#27 powders (with particle size of $\sim 10 \mu \mathrm{m}$ ) using Eq.4.

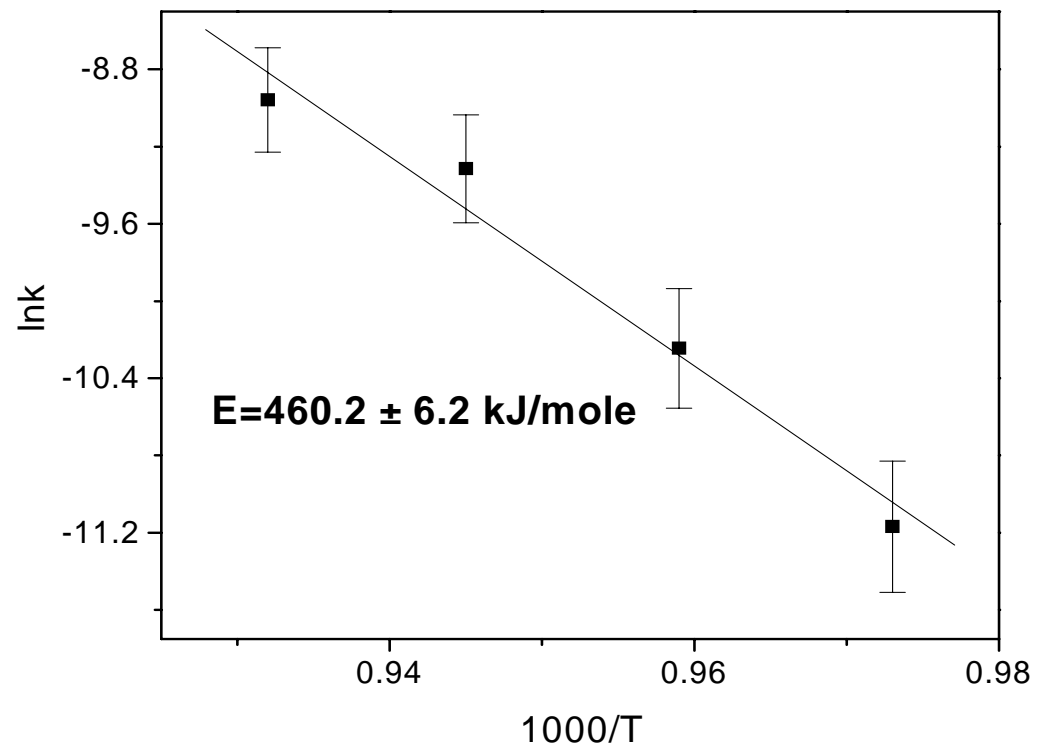

Figure 6: Arrhenius plot (lnk vs $1 / \mathrm{T}$ ) for crystallization of glass \#27 powders with particle size of $\sim 10 \mu \mathrm{m}$. 
Table 2: Values of Avrami exponents and rate constants determined by JMA equation for glass powders with particle size of $\sim 10 \mu \mathrm{m}$.

\begin{tabular}{ccccc}
\hline $\begin{array}{c}\text { Temp } \\
\left({ }^{\circ} \mathbf{C}\right)\end{array}$ & Temp (K) & $\mathbf{1 0 0 0 / T ( 1 / K )}$ & $\mathbf{n}$ & Ink \\
\hline 755 & 1028 & 0.973 & 0.79 & -11.2 \\
770 & 1043 & 0.959 & 1.09 & -10.2 \\
785 & 1058 & 0.945 & 0.94 & -9.3 \\
800 & 1073 & 0.932 & 0.92 & -9.0 \\
\hline
\end{tabular}

Table 3: Activation energy and frequency factors for glass powders and composites.

\begin{tabular}{cccc}
\hline Slass sample & $\mathbf{E}(\mathbf{k J} / \mathbf{m o l e})$ & $\mathbf{k}_{\mathbf{0}}\left(\mathbf{s}^{-\mathbf{1}}\right)$ & $\mathbf{n}$ \\
\hline$\sim 10 \mu \mathrm{m}$ & $460.2 \pm 6.2$ & $3.8 \times 10^{18}$ & $0.93 \pm 0.12$ \\
$45 \sim 53 \mu \mathrm{m}$ & $519.7 \pm 10.7$ & $3.7 \times 10^{19}$ & $1.38 \pm 0.56$ \\
$90 \sim 106 \mu \mathrm{m}$ & $553.9 \pm 3.9$ & $1.6 \times 10^{22}$ & $1.45 \pm 0.17$ \\
$425 \sim 500 \mu \mathrm{m}$ & $570.2 \pm 5.7$ & $1.7 \times 10^{31}$ & $1.58 \pm 0.37$ \\
\hline
\end{tabular}

Figure 7 shows the DTA curves collected from glass \#36 'as cast' and after 30 days at $750^{\circ} \mathrm{C}$. Glass \#36 crystallizes much more slowly at elevated temperatures than many compositions, including glass\#27. As a result, the relatively large crystallization exotherm in the DTA scan of the heat-treated sample in Figure 7 is evidence for a large fraction of residual glass in this sample. Using DTA analyses similar to those described above, the effects of heat-treatment time on the residual glass fraction in samples of glass\#27 and \#36 are summarized in Figure 8. The presence of residual glass could be potentially useful since viscous relaxation at $\mathrm{T}>\mathrm{T}_{\mathrm{g}}$ would help relieve some stresses that would otherwise develop because of CTE-mismatches among the SOFC materials 


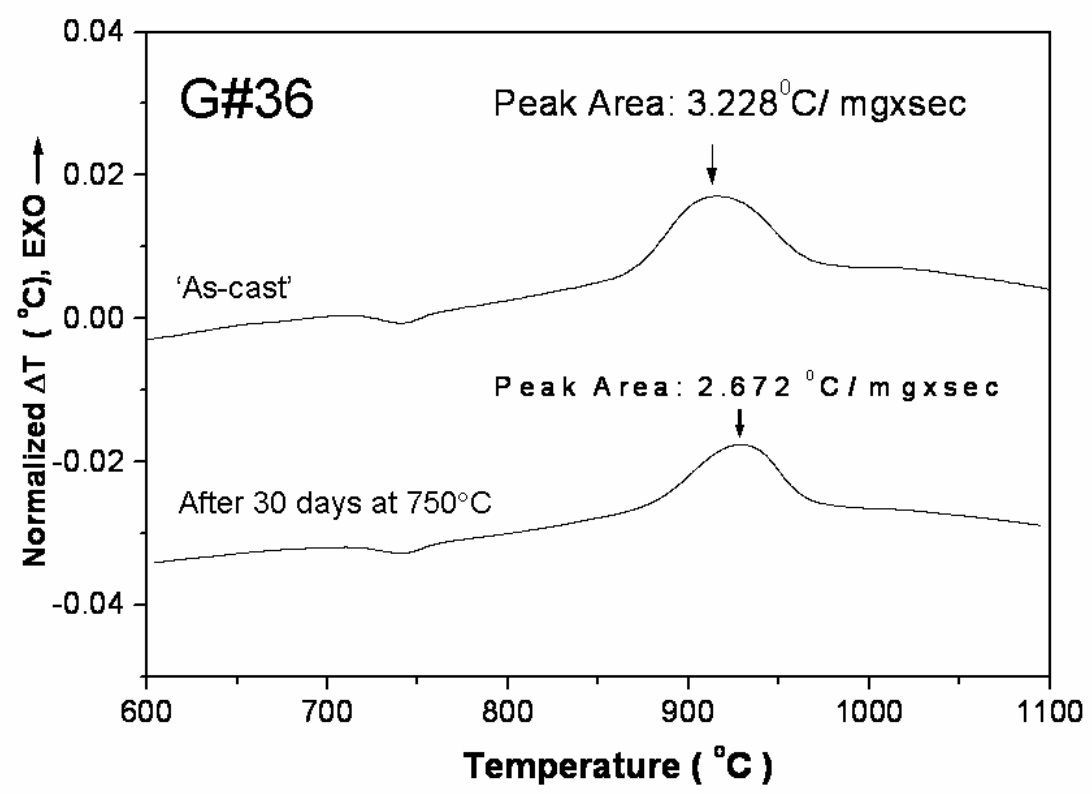

Figure 7: Differential thermal analysis data collected from glass \#36 in the 'as cast' state (top), after a typical sealing treatment: $850^{\circ} \mathrm{C}$ for two hours (middle), and after 30 days at $750^{\circ} \mathrm{C}$ (bottom).

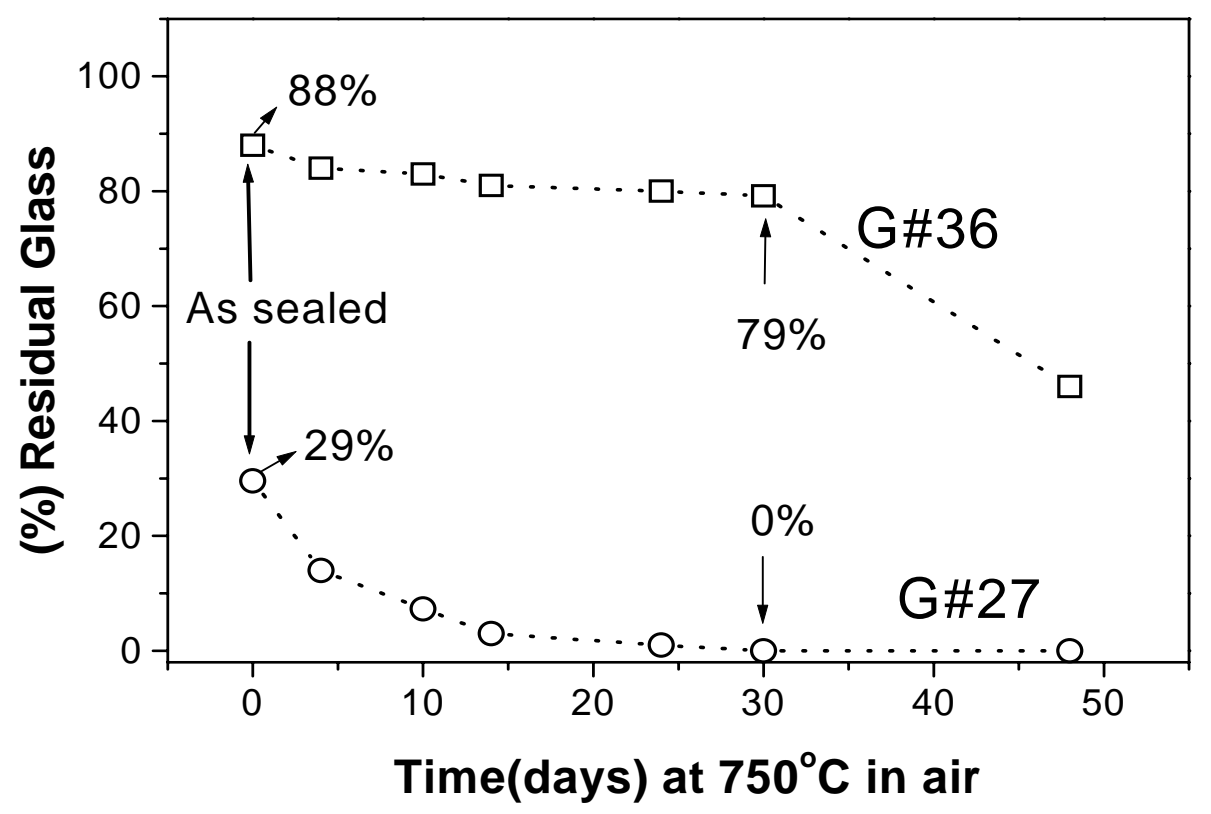

Figure 8: Percent residual glass measured by DTA as a function of time at $750^{\circ} \mathrm{C}$ in air. 


\section{B. Thermal Properties}

Figure 9 shows examples of the dilatometric data collected from glass \#50 'as cast', after initial crystallization during a typical sealing treatment $\left(850^{\circ} \mathrm{C}\right.$ for two hours), and after one month at $800^{\circ} \mathrm{C}$. The 'as cast' glass exhibits a glass transition temperature $\left(\mathrm{T}_{\mathrm{g}}\right)$ of $690^{\circ} \mathrm{C}$ and a dilatometric softening temperature $\left(T_{d}\right)$ of $750^{\circ} \mathrm{C}$. After thirty days at $800^{\circ} \mathrm{C}$, the crystallized sample does not possess an obvious glass transition or softening point. The coefficients of thermal expansion for each sample are similar. The data shown in Figure 9 are representative of the dilatometric data collected from the other 'invert' glasses prepared for this study.

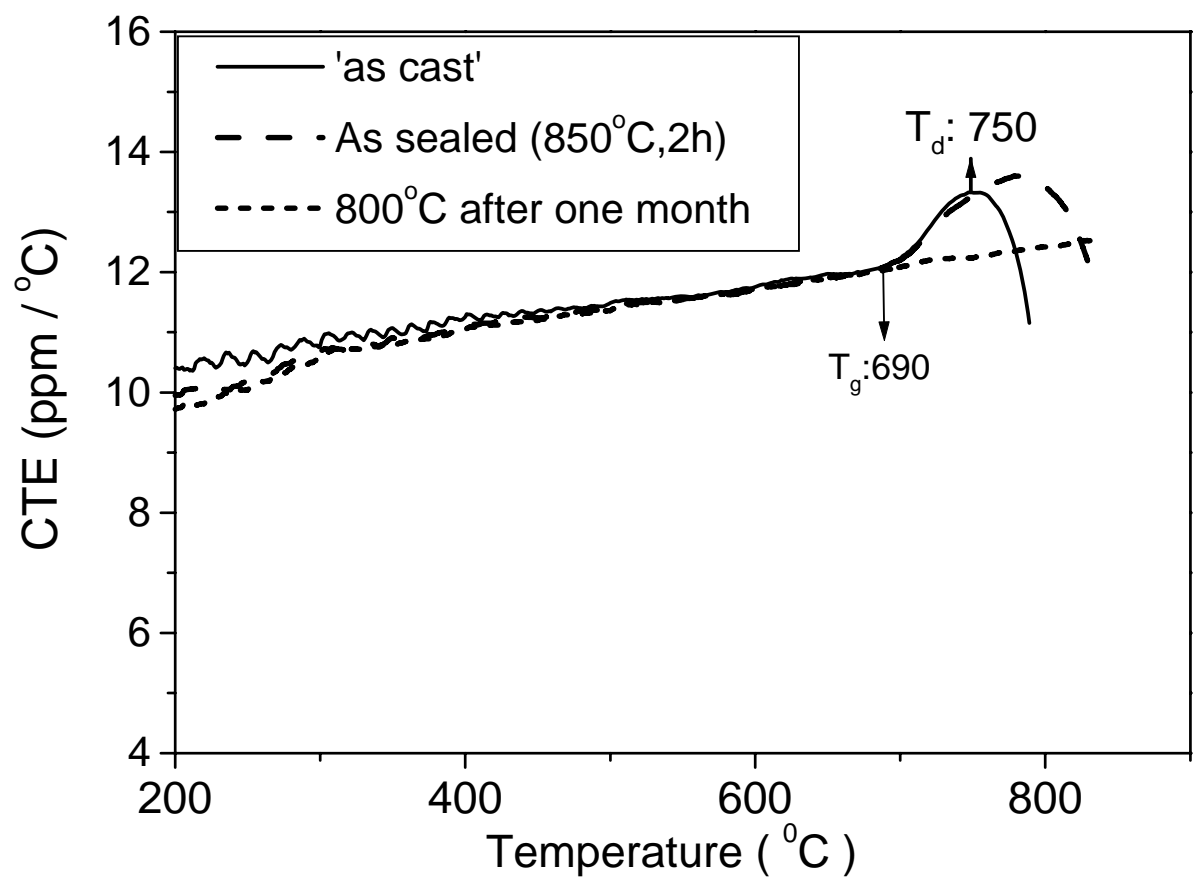

Figure 9: Dilatometric curves collected from glass $\# 50$ 'as cast' and after a typical sealing treatment $\left(850^{\circ} \mathrm{C}\right.$ for two hours).

Some of the thermal properties of the invert glasses and resulting glass-ceramics are summarized in Figure 10, which compares the dilatometric softening points $\left(T_{d}\right)$ of the 'as cast' glasses with the coefficients of thermal expansion (CTE) of those glasses after crystallization, typically done at $850-900^{\circ} \mathrm{C}$ for two hours. The dilatometric softening point is useful as a predictor of the expected sealing temperature of an 'as cast' glass. 
Also shown, for comparison, are the CTE's of yttria-stabilized zirconia (YSZ) and the ferritic stainless steel interconnect alloy 430. Two glass compositions, glass \#27 and glass\#50, are highlighted. These glasses have been evaluated most closely for their suitability as SOFC sealants, and those studies will be described as part of the final report for project

DE-FG26-

04NT42221.

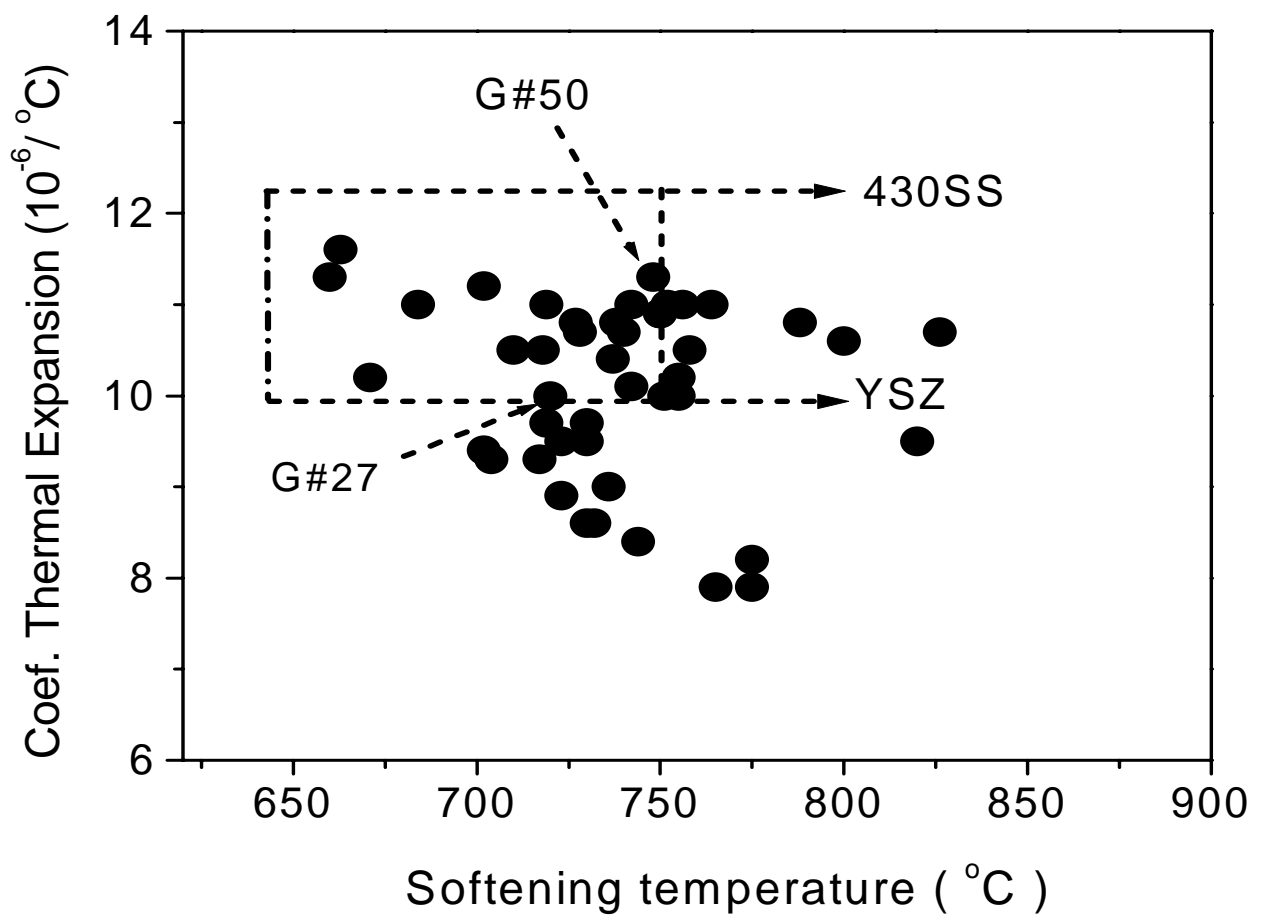

Figure 10: A summary of the dilatometric softening temperatures $\left(T_{d}\right)$ of 'as cast' glasses and the thermal expansion coefficients of the crystallized glasses. The highlighted area represents the target thermal properties for SOFC sealing glasses, based on the CTE values for YSZ and 430SS, as shown.

The emphasis of the present report remains the effects of glass composition on important glass properties, like those summarized in Figure 10. For example, Figure 11 shows that increasing the $\mathrm{B}_{2} \mathrm{O}_{3}$ content of the glass reduces the glass transition temperature, as measured by DTA. The dilatometric softening temperature (not shown) also decreases with $\mathrm{B}_{2} \mathrm{O}_{3}$ content, and as a result, the expected sealing temperature decreases. 


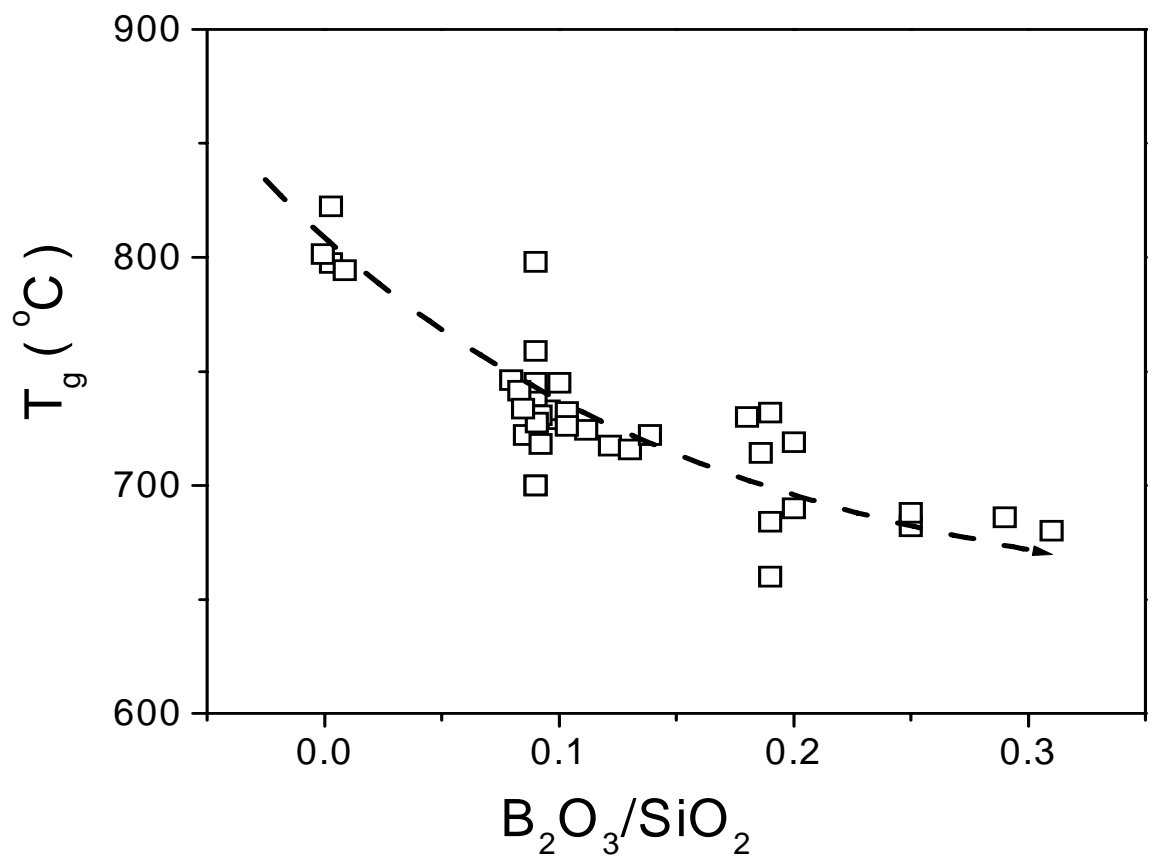

Figure 11: Glass transition temperature (by DTA) versus the $\mathrm{B}_{2} \mathrm{O}_{3} / \mathrm{SiO}_{2}$ molar ratio. The dashed line is drawn as a guide for the eye.

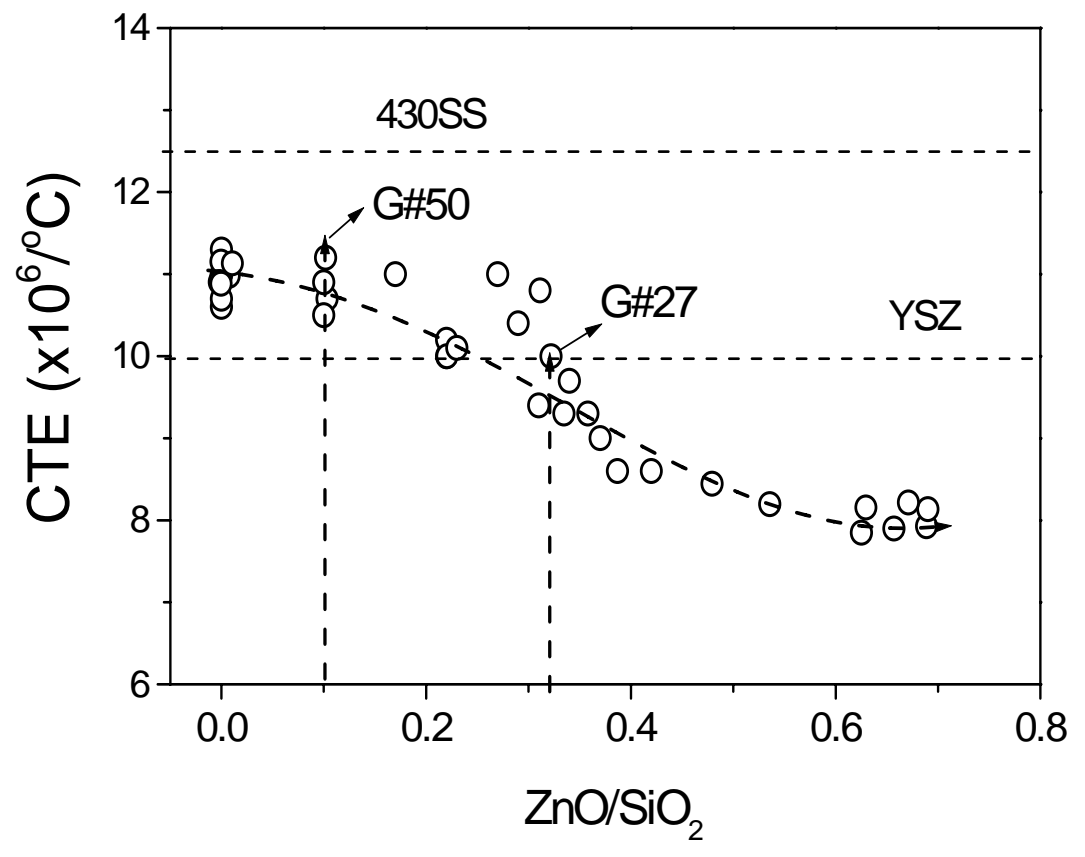

Figure 12: The effect of the molar ratio of $\mathrm{ZnO} / \mathrm{SiO}_{2}$ on the CTE of crystallized "invert" silicate glass-ceramics. The CTE values for YSZ and 430SS are shown for comparison. The dashed line is drawn as a guide for the eye. 
The addition of $\mathrm{ZnO}$ to the invert glasses improves the glass forming tendency (Figure 3 ), but decreases the thermal expansion coefficient of the resulting glass-ceramic (Figure 12). Compositions with relatively large $\mathrm{ZnO}$ contents, like glass \#27, produce glassceramics that have thermal expansion coefficients that are good matches to YSZ $\left(\sim 10 \mathrm{ppm} /{ }^{\circ} \mathrm{C}\right)$, whereas compositions like glass \#50, with a lower ZnO-content, have CTE values that are closer matches to 430SS (Figure 12). The thermal expansion coefficient of these 'invert' silicate glasses also depends on the alkaline earth contents, as shown in Figure 13.

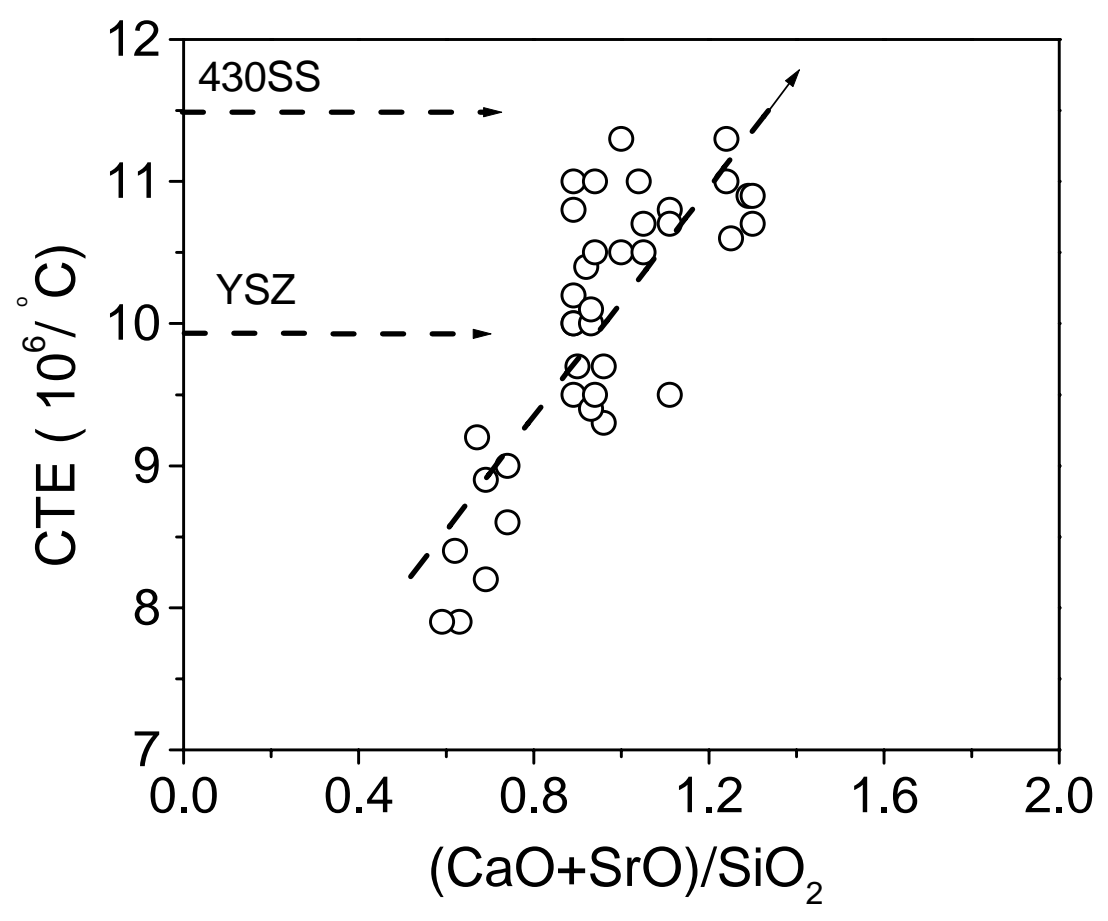

Figure 13: CTE values for crystallized 'invert' silicate glass-ceramics as a function of the $[\mathrm{CaO}+\mathrm{SrO}] / \mathrm{SiO}_{2}$ molar ratio. The straight line is a linear least squares fit of this data.

These results indicate some composition-property trends that are useful for the design of potential SOFC sealing materials. The replacement of $\mathrm{ZnO}$ and/or $\mathrm{B}_{2} \mathrm{O}_{3}$ by $[\mathrm{CaO}+\mathrm{SrO}]$ increases the CTE in the range desired for some SOFC applications. Glasses like glass\#25, \#27 and \#42, with the molar ratio $[\mathrm{CaO}+\mathrm{SrO}] / \mathrm{SiO}_{2} \sim 0.90$, have lower thermal expansion coefficients that match YSZ $\left(\sim 10 \mathrm{ppm} /{ }^{\circ} \mathrm{C}\right)$, whereas compositions like 
glass $\# 35, \# 36$, and $\# 50$, with a greater molar ratio $[\mathrm{CaO}+\mathrm{SrO}] / \mathrm{SiO}_{2}$, have greater CTE values, in the range of $11.5-12.0 \mathrm{ppm} /{ }^{\circ} \mathrm{C}$.

An important consideration for long-term SOFC applications is the thermal stability of the CTE of the sealing material. Figure 14 shows the average CTE (between 200 and $700^{\circ} \mathrm{C}$ ) for four crystallized sealing glasses as a function of time at $800^{\circ} \mathrm{C}$. Two of the compositions, glass \#27 and glass \#50, have relatively stable values of CTE, whereas two others, glasses \#35 and \#36, show significant decreases in CTE, particularly after the first two weeks on test. X-ray diffraction analyses, like those shown in Figure 15, provide an explanation for the temperature-dependence of CTE. Glasses with stable CTE's exhibit no changes with time in their x-ray diffraction patterns, whereas those materials with decreasing CTE's exhibit time-dependences in their phase distributions. The CTE of glasses with low $\mathrm{ZnO}$ content $\left(\mathrm{ZnO} / \mathrm{SiO}_{2}<0.1\right)$ like $\# 35$ and $\# 36$, on the other hand, drops from $11.3 \times 10^{-6} /{ }^{\circ} \mathrm{C}$ to $9.3 \times 10^{-6} /{ }^{\circ} \mathrm{C}$ after 42 days at $800^{\circ} \mathrm{C}$ (Figure 14). Glasses \#35 and \#36 have large fractions of residual glass after their initial sealing cycle (e.g., Figure 8 ), and so they transform to stable crystalline materials more slowly. The decrease in CTE for these latter glasses is accompanied by an increase in the relative fraction of $\mathrm{CaSiO}_{3}$ in the crystallized glass-ceramic (Figure 15) [11]. $\mathrm{CaSiO}_{3}$ has a relatively low $\mathrm{CTE}[12], \sim 6.5 \times 10^{-6} /{ }^{\circ} \mathrm{C}$, and it decreases the net CTE of the glass-ceramic. Glass $\# 50$, with a $\mathrm{ZnO} / \mathrm{SiO}_{2} \sim 0.1$, retains a relatively high CTE $\left(11.4 \times 10^{-6} /{ }^{\circ} \mathrm{C}\right)$ after 120 days at $800^{\circ} \mathrm{C}$ (Figure 14). The XRD patterns collected from the glass $\# 50$ samples (Figure 15) reveals no discernible changes in the distributions of the crystalline phases, $(\mathrm{Ca}, \mathrm{Sr}) \mathrm{SiO}_{3}$, $\mathrm{Sr}_{2} \mathrm{Al}_{2} \mathrm{SiO}_{7}$ and $\mathrm{CaSrSiO}_{4}$, over the course of the long-term heat treatments. 


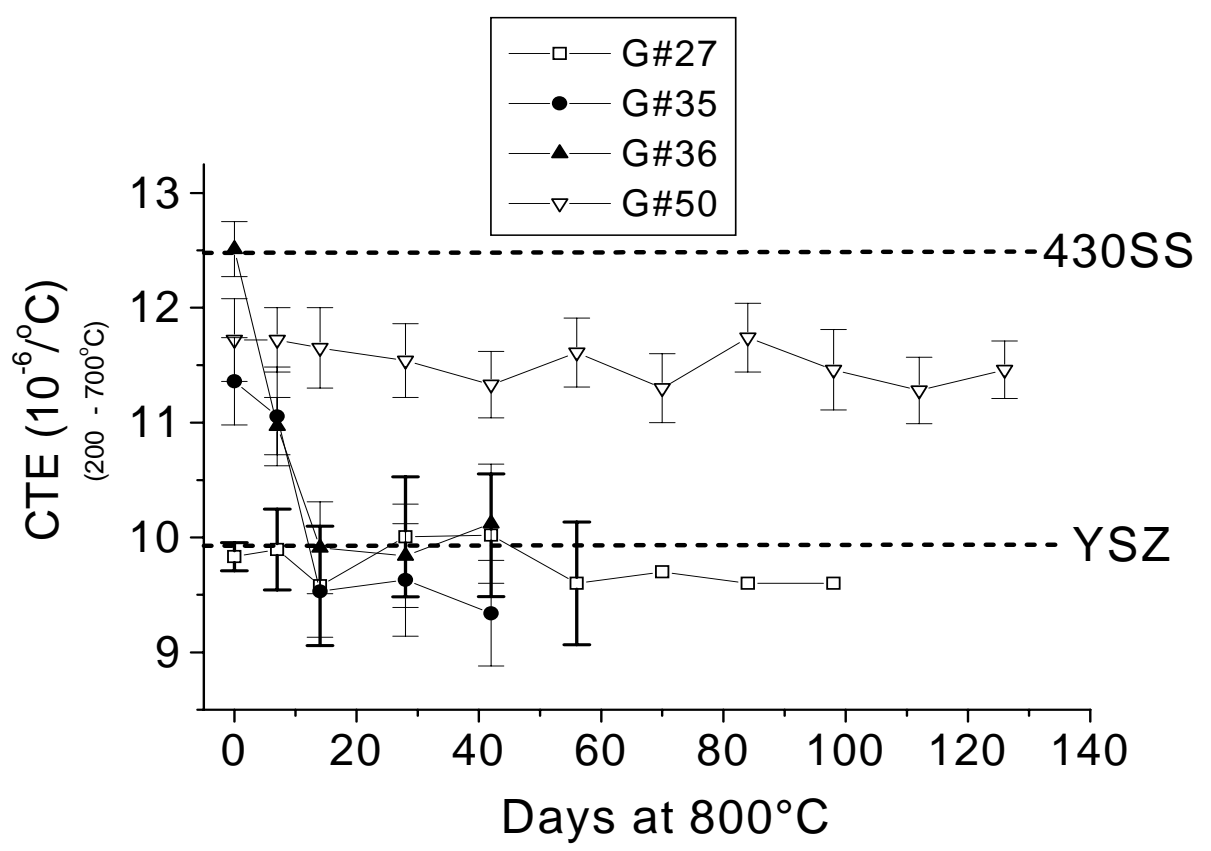

Figure 14: CTE data for crystallized glasses \#27, \#35, and $\# 50$ held at $800^{\circ} \mathrm{C}$ in air for up to 120 days. The 'as received' CTE values for YSZ and 430SS are shown for comparison.
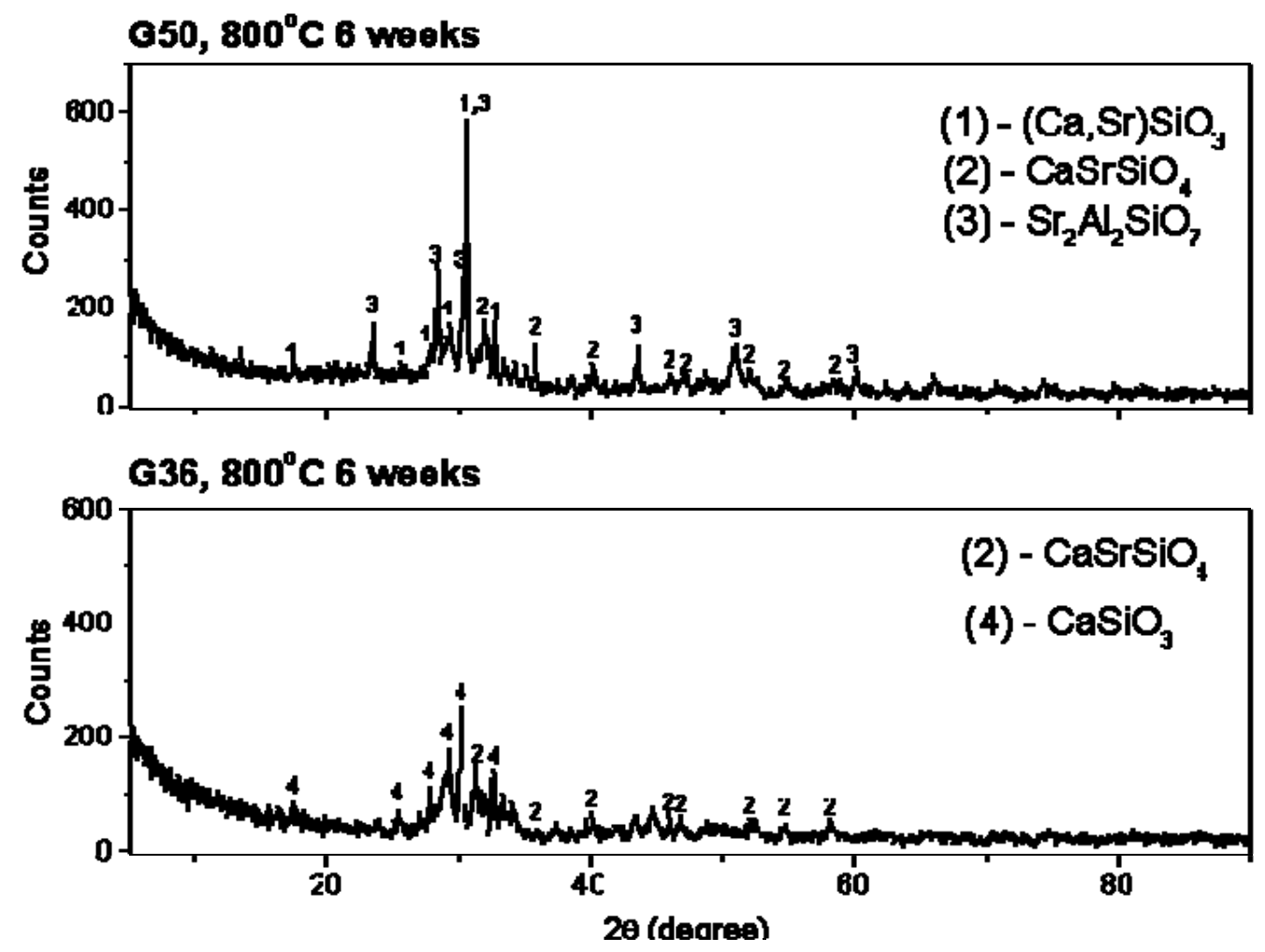

Figure 15: X-ray diffraction data collected from glass \#50 (top) and glass \#36 (bottom) after six weeks at $800^{\circ} \mathrm{C}$. 


\section{High Temperature Stability}

Figure 16 shows the cumulative weight losses from glass-ceramic samples, with $\mathrm{B}_{2} \mathrm{O}_{3} / \mathrm{SiO}_{2}$ molar ratios ranging between 0 and 0.31 , held in wet, flowing forming gas at $800^{\circ} \mathrm{C}$ for up to 28 days. Figure 17 summarizes the effect of $\mathrm{B}_{2} \mathrm{O}_{3}$-content on the weight loss rates; clearly, an increase in the boron content of the glass-ceramic is associated with greater volatilization rates under these conditions. In addition, materials with a greater fraction of residual glass tend to exhibit greater volatilization rates (not shown). These volatilization experiments provide clues about the long-term stability of a proposed sealing system and so place constraints on compositional design. Based on this constraint, the most promising sealing glasses have low $\mathrm{B}_{2} \mathrm{O}_{3}$-contents.

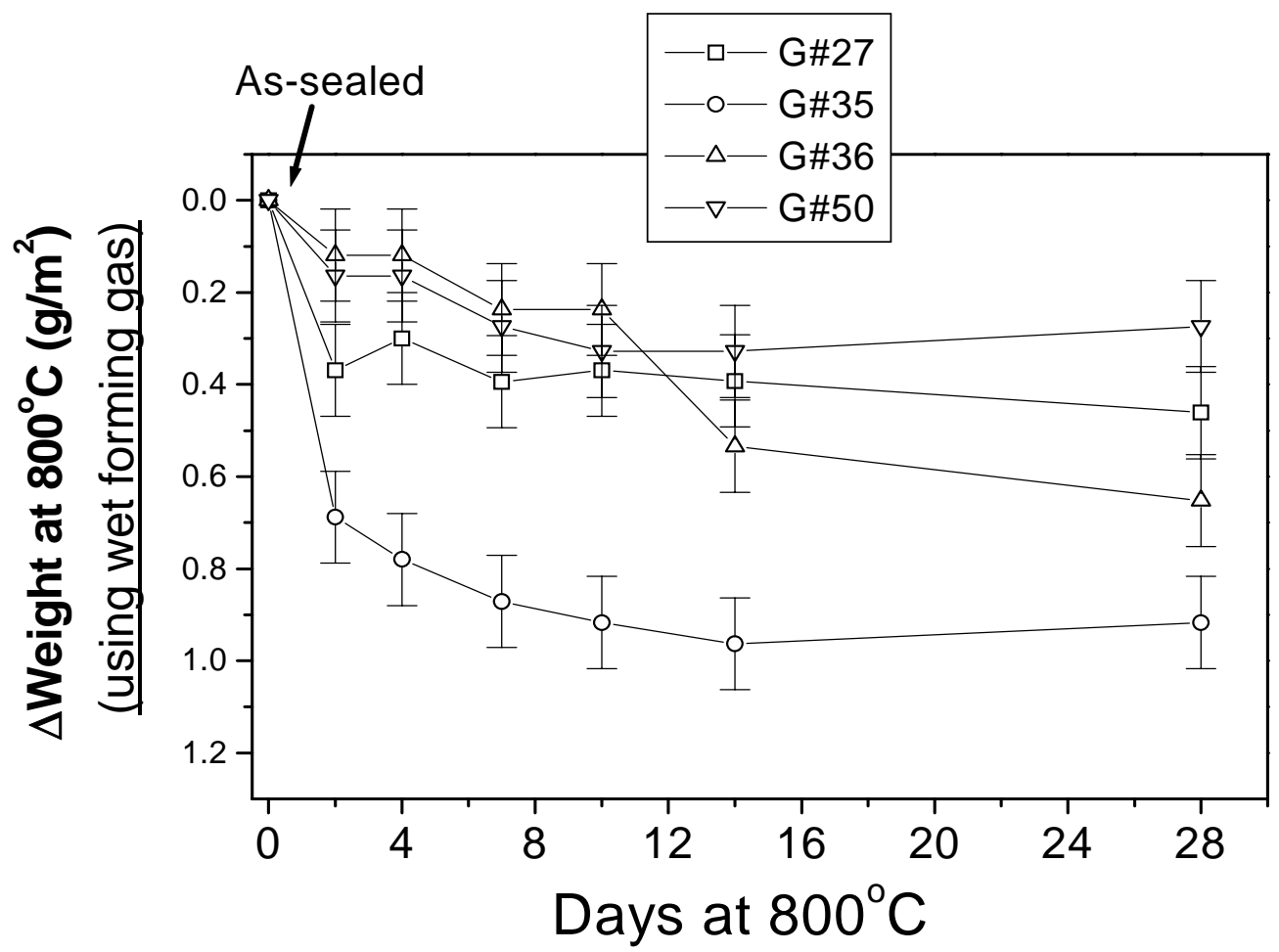

Figure 16: Sample weight losses for up to 28 days at $800^{\circ} \mathrm{C}$ in wet forming gas. The solid lines are drawn as guides for the eye. 


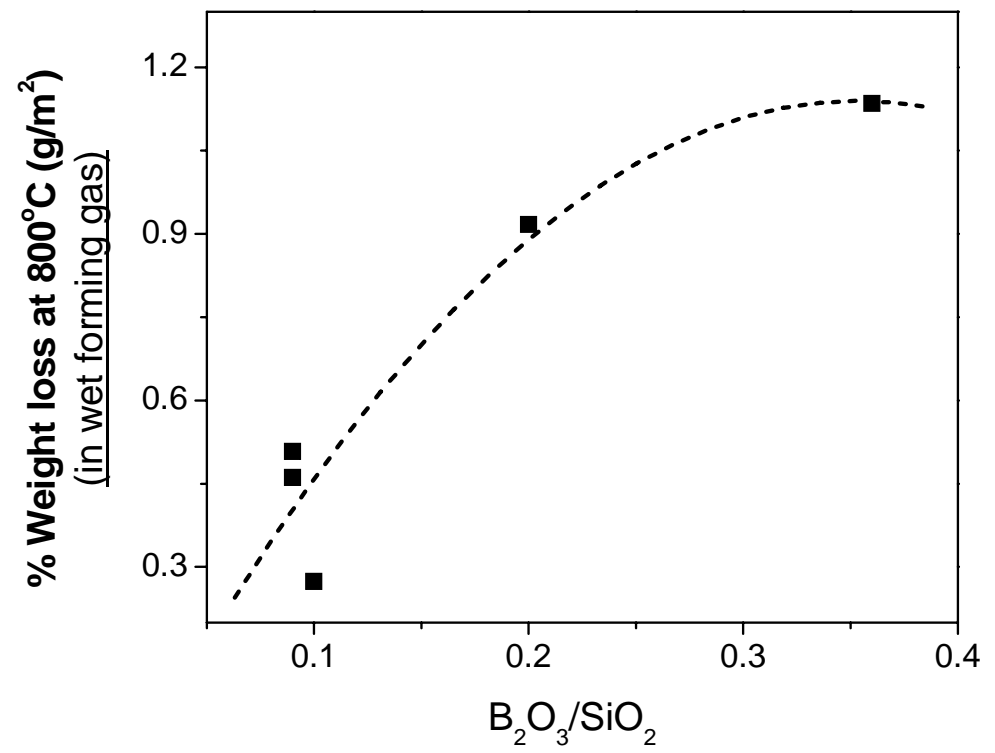

Figure 17: The effect of $\mathrm{B}_{2} \mathrm{O}_{3} / \mathrm{SiO}_{2}$ molar ratio on the cumulative weight lost after 28 days at $800^{\circ} \mathrm{C}$ in wet forming gas. The dashed line is drawn as a guide for the eye.

\section{Development of composite materials}

Glass \#27 was used in a series of composite experiments to characterize the effects of a second phase, including $\mathrm{Ni}$ and YSZ powders, on the properties and crystallization behaviour this sealing glass. Figure 18 shows how the temperature-dependence of the coefficient of thermal expansion changes with the $\mathrm{Ni}$ content for samples heated to $850^{\circ} \mathrm{C}$ for one hour. The CTE of a glass $\# 27 / 10 \mathrm{vol} \% \mathrm{Ni}$ composite is around $11 \times 10^{-6} /{ }^{\circ} \mathrm{C}$, compared with $\sim 10 \times 10^{-6} /{ }^{\circ} \mathrm{C}$ for 'pure' glass $\# 27$ matrix. The greater CTE of the composite material makes it more suitable to seal with SOFC materials that have greater expansion coefficients.

Figure 19 shows an electron micrograph of a glass $\# 27-1$ vol\%Ni composite after an $850^{\circ} \mathrm{C} / 1$ hour sealing cycle, and then a $750^{\circ} \mathrm{C} / 2$ week heat treatment in air. X-ray fluorescence microanalysis (not shown) indicates that the "white lath" particle in this micrograph is a Ni particle. There are no cracks between the $\mathrm{Ni}$ and the glass matrix and there is no evidence for the creation of new phases at the Ni/glass interface, indicating desirable thermo-mechanical and thermo-chemical stability for the composite. The 
thermo-chemical stability of glass \#27 with Ni and with YSZ has been confirmed by Ron Loehman and co-workers at Sandia National Labs (unpublished results).

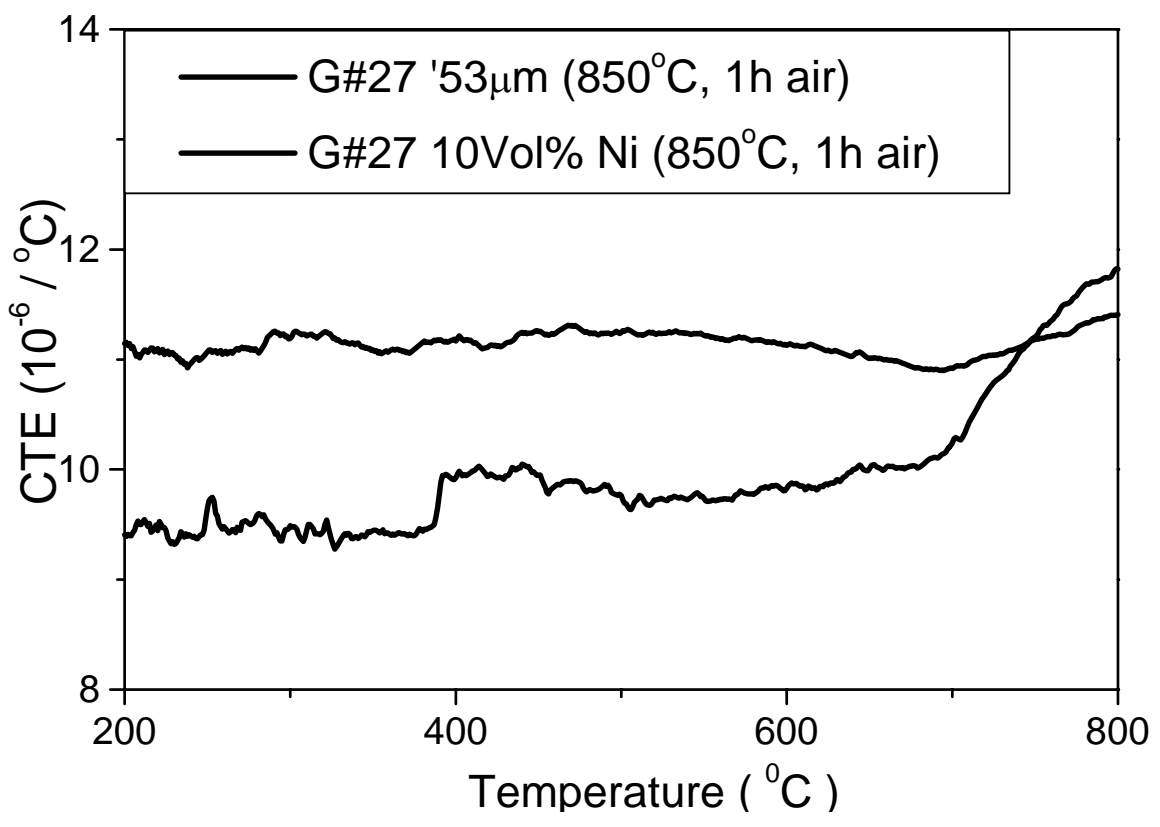

Figure 18: The effect of the addition of $10 \mathrm{vol} \% \mathrm{Ni}$ on the coefficient of thermal expansion of crystallized glass $\# 27$ after one hour at $850^{\circ} \mathrm{C}$. Note that the 'pure' glass \#27 softens near $700^{\circ} \mathrm{C}$.

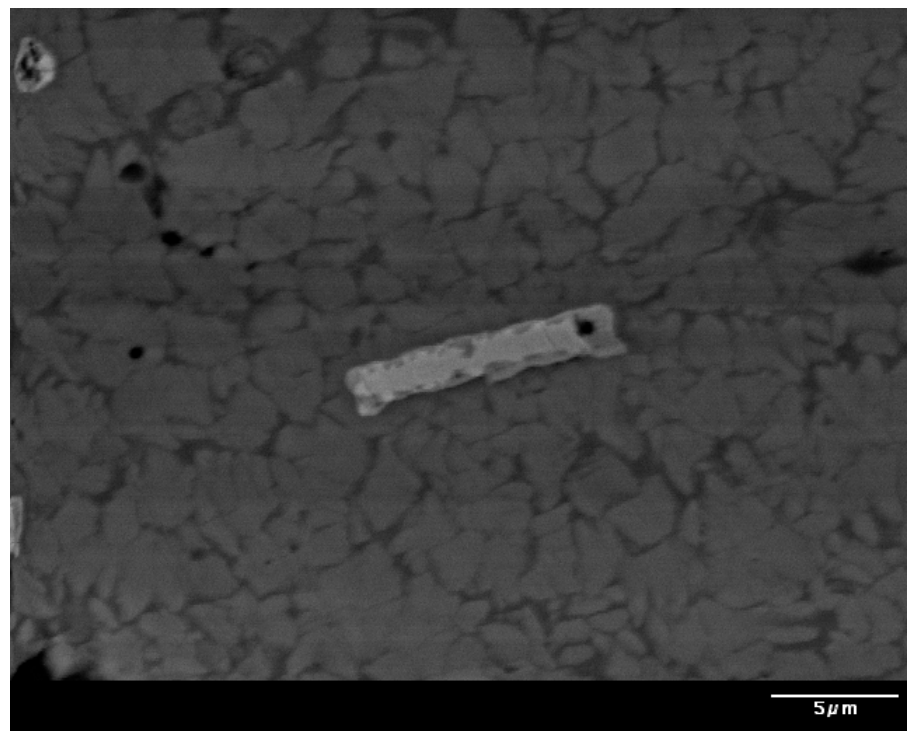

Figure 19: Scanning electron micrograph of a G\#27-1vol\% $\%$ i composite sealed at $850^{\circ}$ $\mathrm{C}$ and then held at $750^{\circ} \mathrm{C}$ for 2 weeks in air. The particle at the center of this micrograph is $\mathrm{Ni}$. 
The addition of a second phase affects the crystallization behaviour of the 'invert' glasses. For example,

Figure 20 shows the DTA results from pure glass \#27, and glass \#27 mixed with $1.6 \mathrm{vol} \% \mathrm{Ni}$ and with $10 \mathrm{vol} \% \mathrm{Ni}$. Note that the temperature of the crystallization exotherm decreases, from $923^{\circ} \mathrm{C}$ to $888^{\circ} \mathrm{C}$ and to $870^{\circ} \mathrm{C}$, respectively, as $\mathrm{Ni}$ is added. Experiments like this provide information about the crystallization kinetics of glassmatrix composites.

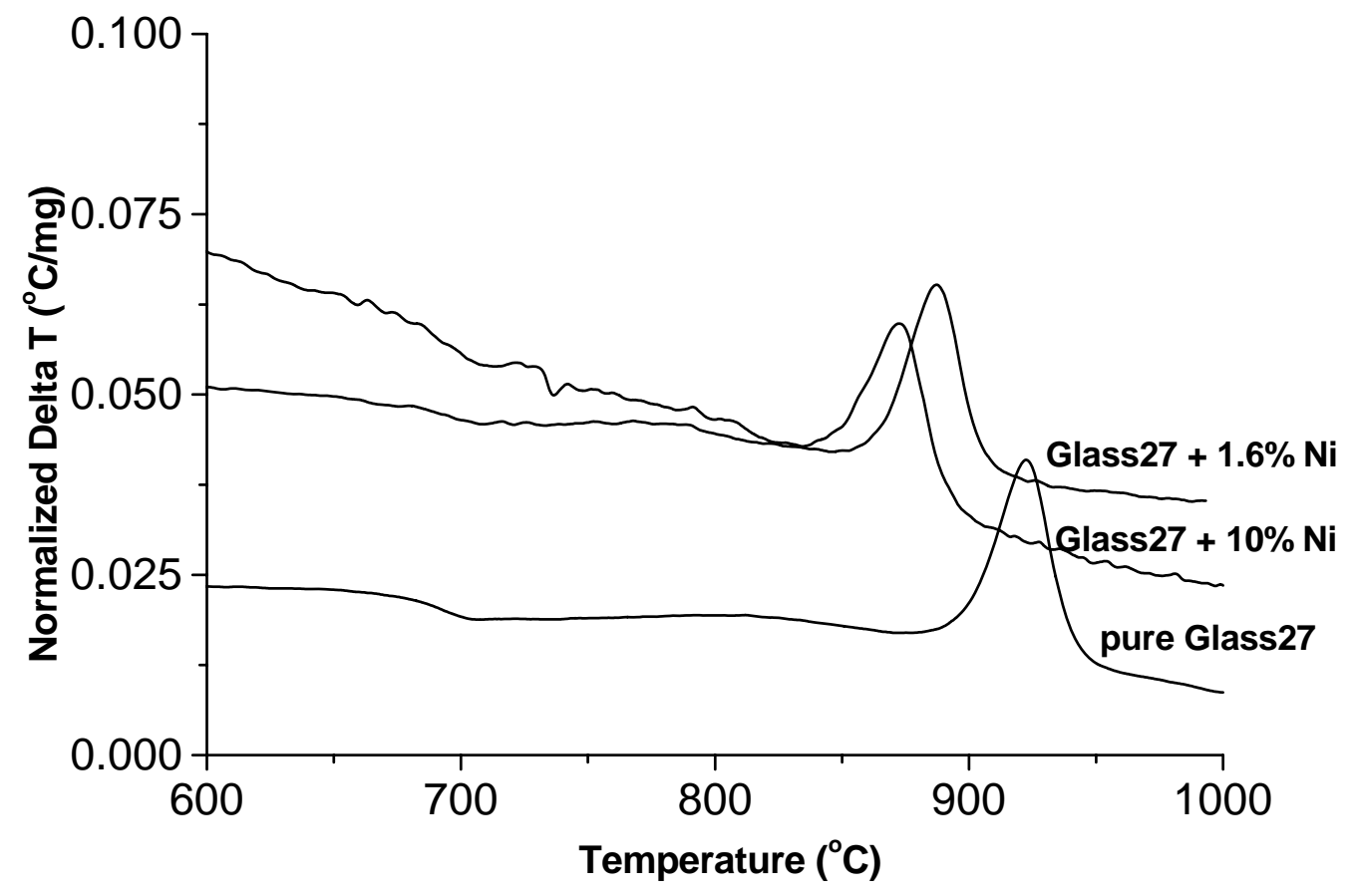

Figure 20: The effect of Ni-additions on the crystallization characteristics of glass \#27, as determined by DTA.

The results of the Avrami calculations (described above) for the composite samples are summarized in Table 4. The Avrami exponent (n) for each sample, including the composites with $10 \mathrm{vol} \% \mathrm{Ni}$ and with $10 \mathrm{vol} \% \mathrm{YSZ}$, are $\sim 1$, indicating that these materials crystallize from the surfaces of the glass particles. The pre-exponential factors for the two composite samples are orders-of-magnitude greater than for the 'base glass' and the activation energies are greater $(\sim 600 \mathrm{~kJ} / \mathrm{mole}$ vs. $\sim 520 \mathrm{~kJ} / \mathrm{mole})$. These trends are consistent with those reported in the literature [13] that discuss the contributions of nucleation agents to faster crystallization kinetics. Figure 21 illustrates the effects of the 
addition of 10vol\% Ni powder on the crystallization kinetics of glass \#27 at two different temperatures. The results were obtained by DTA experiments like those discussed in reference [9] and clearly show that the Ni powder accelerates glass crystallization.

Table 4: Activation energy (E) and Avrami transformation factors for glass\#27 composites.

\begin{tabular}{cccl}
\hline Glass sample & $\mathrm{E}(\mathrm{kJ} / \mathrm{mole})$ & $\mathrm{k}_{0}\left(\mathrm{~s}^{-1}\right)$ & $\mathbf{n}$ \\
\hline $45 \sim 53 \mu \mathrm{m}$ & $519.7 \pm 10.7$ & $3.7 \times 10^{19}$ & $1.38 \pm 0.56$ \\
$45-53 \mu \mathrm{m}$ with & $599.0 \pm 20.7$ & $3.1 \times 10^{25}$ & $0.99 \pm 0.17$ \\
$10 \mathrm{vol} \% \mathrm{Ni}$ & & & \\
\hline $\begin{array}{c}45-53 \mu \mathrm{m} \text { with } \\
10 \text { vol \% YSZ }\end{array}$ & $597.4 \pm 46.0$ & $1.0 \times 10^{25}$ & $0.74 \pm 0.14$ \\
\hline
\end{tabular}

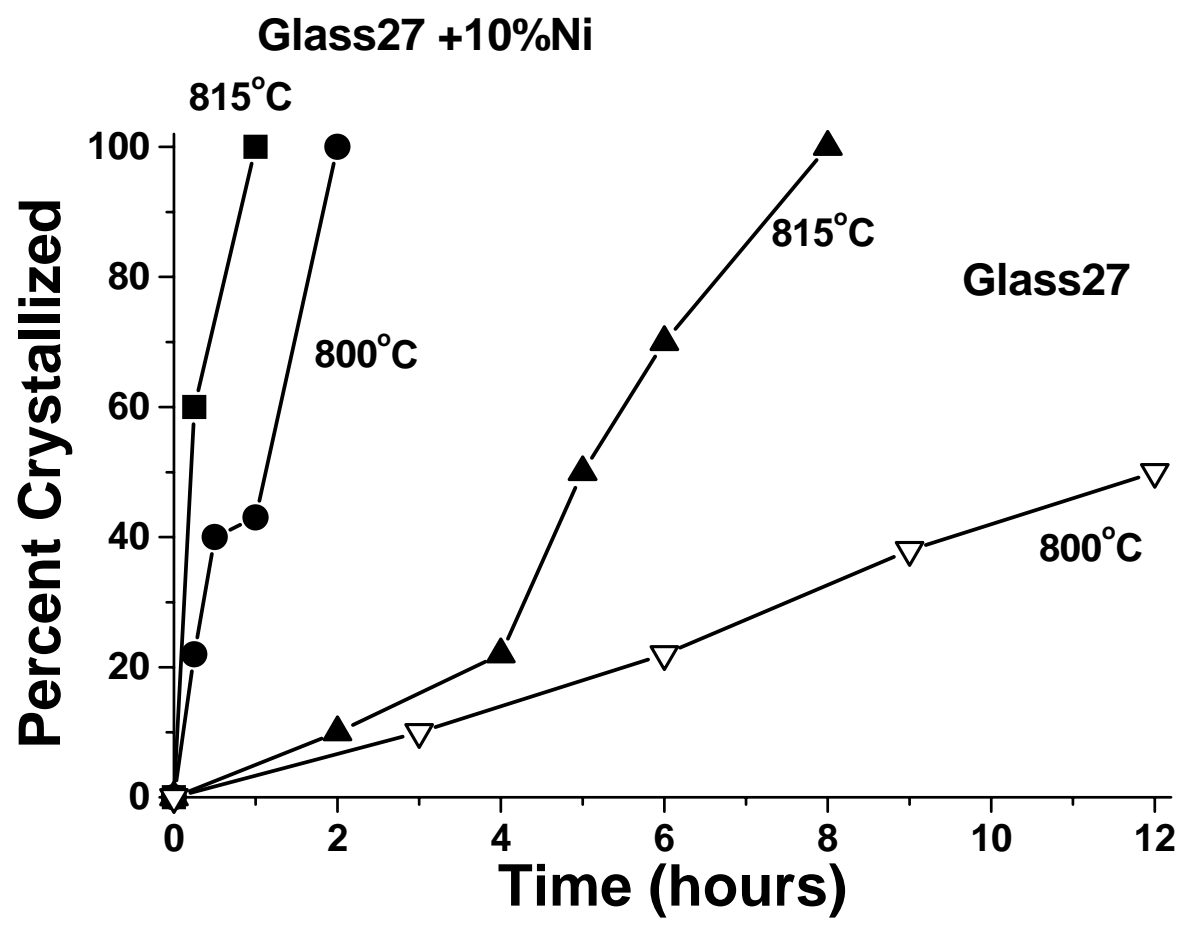

Figure 21: Crystallization kinetics at two temperatures for glass \#27 with and without 10vol\%Ni powder, as measured by DTA. 


\section{Conclusions}

The alkaline earth/zinc oxide silicate 'invert' glass system was studied and several promising glass compositions were identified as candidates for sealing materials for SOFC applications. (The sealing experiments will be described in a separate report for SECA project DE-FG26-04NT42221.) The effects of composition on critical glass properties were evaluated and a number of useful composition-property trends were identified, including:

- ZnO improves the glass-forming tendency, but decreases the CTE. Glass systems with a $\mathrm{ZnO} / \mathrm{SiO}_{2}$ molar ratio between 0.1 and $\sim 0.3$ have the desirable glass forming characteristics and CTE characteristics required for SOFC sealing applications;

- The CTE of the 'invert' silicate glasses is modified by the relative SrO- and CaOcontents. The glass CTE exceeds $\sim 11 \times 10^{-6} /{ }^{\circ} \mathrm{C}$ when the $[\mathrm{SrO}+\mathrm{CaO}] / \mathrm{SiO}_{2}$ molar ratio $>1.0$, but the glass forming tendency is generally reduced with greater $[\mathrm{SrO}+\mathrm{CaO}]$ contents.

- Thermo-chemical and thermo-mechanical stabilities are critical for long-term applications and are associated with $\mathrm{ZnO}$ and $\mathrm{B}_{2} \mathrm{O}_{3}$ contents. The nature of the residual glass in these glass-ceramics has a significant effect on the thermomechanical stabilities and appears to be related to the $\mathrm{B}_{2} \mathrm{O}_{3}$ content. In addition, glass-ceramics with $\mathrm{ZnO}$ contents greater than about 5 mole\% appear to have better thermo-stabilities than materials with lower $\mathrm{ZnO}$-contents, because $\mathrm{ZnO}$ appears to suppress the formation of low CTE phases like $\mathrm{CaSiO}_{3}$.

Based on these results, the following tasks have been identified to produce a viable hermetic seal for a prototype SOFC design. The results of these experiments are described in the forthcoming report for SECA project DE-FG26-04NT42221.

1. Optimize the composition and sealing conditions for the 'invert' glass-ceramics. Glass\#27 and glass\#50 are particularly interesting; recent experiments at UMR indicate the possibility of producing a sealing material with desirable viscosity (flow) and thermal expansion characteristics at temperatures as low as $800^{\circ} \mathrm{C}$. 
Compositional modifications to tailor that material for Ni-YSZ/430SS seals should be done, and experiments should be performed to characterize the longterm thermal stability of the glass-ceramics (at $800^{\circ} \mathrm{C}$ or other temperature recommended by the SECA partners).

2. Investigate in more detail the effects of $\mathrm{ZnO}$ on the thermo-mechanical and thermo-chemical stability of new glass systems under SOFC operational condition.

3. Investigate the influence of the $\mathrm{B}_{2} \mathrm{O}_{3}$ content on the residual glass of glassceramic under SOFC condition. The presence of residual glass could be potentially positive since viscous relaxation would help relieve some stresses that would otherwise develop because of CTE-mismatches among the cell materials.

4. Characterize the electrical stability of the new sealing materials under oxidizing and reducing conditions. Glass-ceramic samples should be characterized after prolonged (1-7 days) exposure at $800^{\circ} \mathrm{C}$ to forming gas atmospheres to ensure that the seals are stable under SOFC operational conditions.

5. Procedures should be developed for processing glass tapes and films for producing hermetic seals.

\section{References}

1. S. Singhal "Ceramic fuel cells for stationary and mobile applications", Am. Ceram. Soc. Bulletin, 82 (11), 9601-9610 (2003).

2. N. Q. Minh, “Ceramic fuel cells”, J. Am. Ceram. Soc., 76, 563-588 (1993).

3. Z. Yang, J. W. Stevenson and K. D. Meinhardt, "Chemical interactions of bariumcalcium-aluminosilicate-based sealing glasses with oxidation resistant alloys ", Solid State Ionics, 160, 213-225 (2003).

4. S. B. Sohn, S. Y. Choi, G. H. Kim, H. S. Song, G. D. Kim, “ Stable sealing glass for planar solid oxide fuel cell”, J. Non-Cryst. Solids, 297, 103-112 (2002).

5. J. W. Fergus, "Sealants for solid oxide fuel cells", Journal of Power Sources, $\mathbf{1 4 7}$ 46-57 (2005). 
6. Z. Yang, K. D. Meinhardt, and J. Stevenson, "Chemical Compatibility of BariumCalcium-Aluminosilicate-Based Sealing Glasses with the Ferritic Stainless Interconnect in SOFC", J.Electrochem.Soc.,150(8), A1095-A1101(2003).

7. H.J.L Trapp and J.M. Stevels, Phys Chem Glasses 1107 (1960).

8. I. Avramov, E.D. Zanotto, M. O. Prado, "Glass-forming ability versus stability of silicate glasses. Part II", Journal of Non-Crystalline Solids, 320 9-20 (2003).

9. C. S. Ray, Signo T Reis, Richard K. Brow, T. Zhang "Determining the kinetic parameters for isothermal crystallization of glasses" accepted for publication in the Journal of the American Ceramic Society, JACERS-22172.R1 06-Nov-2006.

10. X.J. Xu, C. S. Ray and D. E. Day, "Nucleation and Crystallization of $\mathrm{Na}_{2} \mathrm{O}-2 \mathrm{CaO}-$ $3 \mathrm{SiO}_{2}$ Glass by Differential Thermal Analysis," J.Am.Ceram.Soc.,74[5]909-914 (1991).

11. S. T. Reis and R. K. Brow "Designing Sealing Glasses for Solid Oxide Fuel Cells", Journal of Materials Engineering and Performance, 15410 - 413 (2006).

12. W. Höland and G. Beall, "Glass Ceramic Technology" American Ceramic Society, Westerville, $\mathrm{OH}(2000)$.

13. C. S. Ray, W. H. Huang and D. E. Day, "Crystallization Kinetics of a Lithia- Silica Glass: Effect of Composition and Nucleating Agent," J.Am.Ceram.Soc.,70[8]599603 (1987). 


\section{Journal Articles, Conference Papers and Proceedings Generated}

1. S.T. Reis, R.K. Brow, "Designing Sealing Glasses for Solid Oxide Fuel Cells," Journal of Materials Engineering and Performance, 15[4], 410-414 (2006)- (Proceedings of the ASM Materials Solution Conference, Fuel Cells: Materials, Processing and Manufacturing Technologies, Columbus, OH Oct. 18-20, 2004)

2. S.T. Reis, R.K. Brow. P. Jasinski, and T. Zhang, "Properties of Glass-Ceramic Seals for Solid Oxide Fuel Cells," Advances in Solid Oxide Fuel Cells II, Ceramic Engineering and Science Proceedings, Cocoa Beach, Volume 27, Issue 4, proceedings of the $3^{\text {rd }}$ International Symposium on Solid Oxide Fuel Cells, $30^{\text {th }}$ International Conference \& Exposition on Advanced Ceramics \& Composites, Cocoa Beach, FL, Jan. 22-27, 2006.

3. C. S. Ray, T. Zhang, S. T. Reis, and R. K. Brow, "Determining Kinetic Parameters for Isothermal Crystallization of Glasses," (submitted to the J. American Ceramic Society, August 2006; accepted Nov. 2006).

\section{Conference Presentations}

1. T. Zhang*, S. T. Reis, R. K. Brow, and C.S. Ray, "Crystallization Studies of SOFC Sealing Glasses," $3^{\text {rd }}$ International Symposium on Solid Oxide Fuel Cell: Materials and Technology, $30^{\text {th }}$ International Conference \& Exposition on Advanced Ceramics \& Composites, Cocoa Beach, FL, Jan. 22-27, 2006.

2. S.T. Reis*, R.K. Brow, and T. Zhang, "Glass-Ceramic Seals for Solid Oxide Fuel Cells: Thermo-Phase Stability," $3^{\text {rd }}$ International Symposium on Solid Oxide Fuel Cell: Materials and Technology, $30^{\text {th }}$ International Conference \& Exposition on Advanced Ceramics \& Composites, Cocoa Beach, FL, Jan. 22-27, 2006.

3. R.K. Brow, "Sealing Glasses for Solid Oxide Fuel Cells," $17^{\text {th }}$ University Conference on Glass Science and $1^{\text {st }}$ International Materials Institute Workshop on "New Functionality in Glasses”, Penn Stater Conference Center Hotel, State College, PA, June 26-30, 2005. (INVITED)

4. R.K. Brow, "Thermochemically stable sealing materials for solid oxide fuel cells," Solid State Energy Conversion Alliance $6^{\text {th }}$ Annual Workshop, Pacific Grove, CA, Apr. 18-21, 2005. (INVITED)

5. Teng Zhang*, S. T. Reis, and R. K. Brow, "Glass Seals for Solid Oxide Fuel Cells," $107^{\text {th }}$ Annual Meeting of the American Ceramic Society, Baltimore, MD, April 10-13, 2005.

6. R.K. Brow*, "Glass Seals for Solid Oxide Fuel Cells," Iowa State Materials Science \& Engineering Seminar, Ames, IA, March 3, 2005. (INVITED)

7. R.K. Brow*, T. Zhang, and S.T. Reis, "Thermochemically Stable Sealing Materials for Solid Oxide Fuel Cells," SECA Core Technology Workshop, Tampa, FL, Jan. 27, 2005.

8. S. T. Reis*, R. K. Brow, and P. Jasinski, "Developing Glass Seals for Solid Oxide Fuel Cells," $2^{\text {nd }}$ International Symposium on Solid Oxide Fuel Cells: Materials and Technology, $29^{\text {th }}$ International Cocoa Beach Conference and Exposition on Advanced Ceramics and Composites, Cocoa Beach, FL, January 23-28, 2005.

9. R. K. Brow and S.T. Reis, "Designing Sealing Glasses for Solid Oxide Fuel Cells," ASM Materials Solution Conference, Fuel Cells: Materials, Processing and Manufacturing Technologies, Columbus, OH Oct. 18-20, 2004 (INVITED). 